\title{
Ders Kitabı Yazarlarının Görüşlerine Göre Yabancı Dil Olarak Türkçe Öğretimi
}

\author{
Efecan Karagöl*, Berker Kurt**
}

Makale Geliş Tarihi: 28/12/2020

Makale Kabul Tarihi: 27/01/2021

DOI: $10.35675 /$ befdergi. 850653

$\ddot{O} z$

Bu araştırmanın amacı ders kitabı yazarlarının yabancı dil olarak Türkçe öğretimine ilişskin görüşlerini tespit etmektir. Araştırmanın alt problemleri; müfredat, beceri, dil bilgisi ve söz varlığı öğretimine ilişkin yazarların görüşlerini ortaya koyacak biçimde oluşturulmuştur. Nitel olarak tasarlanan araştırmanın çalışma grubunu yabancı dil olarak Türkçe öğretimi alanında ders kitabı yazarlı̆̆ yapmış on üç katılımcı teşkil etmiştir. Veriler yar yapılandırllmış görüşme formu ile elde edilmiştir ve içerik analizi tekniği ile incelenmişstir. Araştırma sonucunda ortak müfredatın olması, bütünleşik beceri ögrretiminin yapılmasl, dil bilgisi ögretiminin metin ve beceri temelli olmasl, söz varlı̆̆ öğretiminin daha çok kelimenin anlamını tahmin etme stratejisine dayalı yapılması gibi tespitler elde edilmiştir.

Anahtar Kelimeler: Ders kitabl yazarı, dil becerileri, müfredat, yabancı dil olarak Türkçe ögretimi

\section{Teaching Turkish as a Foreign Language According to the Views of Textbook Authors}

\begin{abstract}
The aim of this research is to determine the opinions of textbook authors on teaching Turkish as a foreign language. The sub-problems of the research reveal the opinions of the authors on teaching curriculum, skills, grammar and vocabulary. The research is qualitatively designed. The study group of the research consists of thirteen participants who are textbook authors in the field of teaching Turkish as a foreign language. The data were obtained using a semi-structured interview form. Content analysis technique was used for data analysis. As a result of the research, it was determined that there is a common curriculum, integrated skills teaching, grammar teaching is text and skill based, vocabulary teaching is based on the strategy of guessing the meaning of the word.
\end{abstract} author

Keywords: Curriculum, language skills, teaching Turkish as a foreign language, textbook

\section{Giriş}

Yabancı dil olarak Türkçe öğretimi alanını teori ve uygulama olarak ikiye ayırmak mümkündür. Teori alanı; müfredat, yöntem, yaklaşım, teknik ve stratejiler gibi bilgileri üretmek veya var olan bilgiler üzerine inceleme, uyarlama ve

* Zonguldak Bülent Ecevit Üniversitesi, Zonguldak, Türkiye, efecankaragol@ gmail.com, ORCID: 00000003-0331-8009 iD

** Akdeniz Üniversitesi, Antalya, Türkiye, berkerakdeniz@gmail.com, ORCID: 0000-0003-4788-0909

Kaynak Gösterme: Karagöl, E. \& Kurt, B. (2021). Ders kitabı yazarlarının görüşlerine göre yabancı dil olarak Türkçe öğretimi. Bayburt Eğitim Fakültesi Dergisi, 16(Özel Say1), 184-209. https://doi.org/10.35675/befdergi.850653 
karşılaştırmalar yapmak gibi bilimsel bilgi amacı taşır. Mevcut bilgilerin hedef kitle ile buluşması veya buluşturulması da uygulama alanını ihtiva eder. Bu yönüyle teori ile uygulama birbirini besleyen alanlardır. Uluslararası öğrencilere Türkçe dil becerilerinin kazandırılması sürecine dâhil olan her paydaşın (öğretmen, ders kitabı yazarı, müfredat yazarı) teori ve uygulama bilgisine sahip olması gerekir. Yabancı dil olarak Türkçe öğretimi alanında özellikle çeşitli resmî kurumlar bünyesinde ders kitabı yazarlığı yapan paydaşların teori ve uygulama bilgisine sahip olduğu düşünülebilir.

Yabancı dil olarak Türkçe öğretimi; öğrencilerin -dil becerileri olarak bilinendinleme, konuşma, okuma ve yazma alanlarında iletişim becerilerini kazanmasını hedefler. Bu hedefin gerçekleşmesi için öğrenci, öğretmen, ders kitabı ve müfredat başta olmak üzere çeşitli etkenlerin var olması gerekir. Belirtilen etkenlerin içinde ders kitabı yazarları diğerlerinden birçok yönüyle ayrılır. Öncelikle yabancı dil olarak Türkçe öğretimi alanında ders kitabı yazarlığı yapanların bir kısmı uluslararası öğrencilere Türkçe öğretme tecrübesine sahiptir. Ayrıca kitap yazımı öncesinde ve sırasında esas alınan müfredatın ilkelerini uygulamaktadır. Diğer bir deyişle müfredatın yazılı ilkelerini ders kitabını oluşturma aşamasında üretime dönüştürmektedir. Bunun yanı sıra yazılan kitapların sınıf içinde uygulamasını yaptıklarından kitaba yönelik eleştirel bakış açısına sahip olabilmektedir. Belirtilen nedenlerden dolayı ders kitabı yazarlarının düşünceleri yabancı dil olarak Türkçe öğretimi alanı açısından dikkate değerdir.

Yeni ve hızlı bir gelişim göstermekte olan yabancı dil olarak Türkçe öğretimi alanının durumu, eksikleri ve ihtiyaçları üzerine birçok bilimsel çalışma yapılmıştır. Literatürde müfredat, yaklaşım, yöntem, teknik ve stratejiler, ders araç gereçleri, ölçme ve değerlendirme ile dil becerileri gibi konular gerek kendi özellikleri veya işlevleri gerekse alana dâhil olan araştırmacı, öğretici/öğretmen/okutman, öğretmen adayı ve öğrenci gibi farklı paydaşların görüşleri çerçevesinde incelemeye tabi tutulmuştur (Alyılmaz \& Şengül, 2017; Aydın, 2015; Balcı \& Dündar, 2017; Balc1 \& Melanlığlu, 2016; Balcı \& Melanlıoğlu, 2020; Başkan \& Ustabulut 2020; Başutku, 2018; Boylu \& Çangal, 2015; Çerçi, 2018; Demirel, 1989; Deniz \& Çekici, 2019; Derman, 2010; Elemen, 2018; Göçen, 2019; Göçer, 2009; Güler, 2012; İşcan, 2011; Jeon, 2017; Kan, Sülüşoğlu \& Demirel, 2013; Karababa, 2009; Karababa, 2010; Karagöl, 2020a; Karagöl 2020b; Kaya \& Kardaş, 2020; Koçer, 2013; Korkmaz, 2018; Kurt, 2020; Kurt, Direkci \& Caner, 2018; Kurudayığlu \& Sapmaz, 2016; Maden \& Dincel, 2017; Memiş, 2019; Mete 2012a; Mete, 2012b; Mete \& Gürsoy 2013; Öztürk \& Alan, 2019; Sallabaş, 2012; Sevim \& Abukan, 2020; Şahbaz \& Çevik, 2018; Şimşek, 2017;Tabak \& Göçer, 2017; Tüm, 2020; Ustabulut \& Kara, 2019; Ustabulut \& Keskin 2020; Ülper, Çetinkaya \& Bayat, 2016; Yaylı \& Yayl1, 2018). Belirtilen çalışmalarda genellikle öğretmen, öğrenci görüşleri ve materyal incelemeleri yoğunluk kazanırken alanın işleyişinde önemli bir yere sahip olan ders kitabı yazarlarının bilimsel araştırmalarda ihmal edildiği görülmektedir. Oysa ders kitabı yazarları -daha önce ifade edildiği gibi- sadece eser ortaya koyan değil, aynı zamanda yabancı dil olarak Türkçe öğretimi alanının bağlantılarını sağlayan önemli bir paydaştır. Ders kitabı yazarları, ürettikleri ders kitaplarında güncel/geçerli teorik bilgiyi işlevsel biçimde uygulama görevini yerine getirmesi nedeniyle teori ve uygulama alanının her ikisine de hâkim olma sorumluluğuna 
sahiptir. Bu yönüyle ders kitabı yazarları, yabancı dil olarak Türkçe öğretimi alanının mevcut durumu, gelişimi ve ihtiyaçlarını tespit edebilecek bilgi birikimine ayrıca görüşleriyle alana yön verebilecek bir niteliğe sahiptir. Belirtilen eksiklik ve gereklilikten hareketle araştırmanın amacı ders kitabı yazarlarının yabancı dil olarak Türkçe öğretimine ilişkin görüşlerini ortaya koymaktır. Bu amaca yönelik ayrıntılı incelemeler yapmak amacıyla aşağıdaki alt problemler belirlenmiştir:

1. Yazarlar, ders kitabını oluştururken hangi müfredatı/müfredatları kullanmıştır?

2. Yazarlara göre ideal bir yabancı dil olarak Türkçe öğretimi müfredatı nasıl olmalidir?

3. Yazarlar, çeşitli kurumların birbirinden farklı müfredata sahip olmasını nasıl değerlendirmektedir?

4. Yazarlara göre ideal bir dinleme/izleme becerisi öğretimi nasıl olmalıdır/neleri içermelidir?

5. Yazarlara göre ideal bir konuşma becerisi öğretimi nasıl olmalıdır/neleri içermelidir?

6. Yazarlara göre ideal bir okuma becerisi öğretimi nasıl olmalıdır/neleri içermelidir?

7. Yazarlara göre ideal bir yazma becerisi öğretimi nasıl olmalıdır/neleri içermelidir?

8. Yazarların dil bilgisi öğretimi hakkında düşünceleri nelerdir?

9. Yazarlara göre söz varlığı öğretimi nasıl yapılmalıdır? Söz varlığ öğretiminde hangi stratejiler kullanılmalıdır?

Ders kitabı yazarlarının yabancı dil olarak Türkçe öğretimi alanına ilişkin görüşlerini ortaya koyması bakımından araştırmanın literatüre katkı sağlayacağı düşünülmektedir. Araştırma resmî kurumların ürettiği ders kitaplarının yazarları ile sınırlandırılmıştır. Özel yayınevlerince yayımlanan kaynak kitapların yazarları araştırmaya dâhil edilmemiştir.

\section{Yöntem}

$\mathrm{Bu}$ başlık altında araştırmanın modeli, çalışma grubu, verilerin toplanması ve analiziyle ilgili bilgilere yer verilmiştir.

\section{Araștırmanın Modeli}

Yabancı dil olarak Türkçe öğretimi ders kitabı yazarlarının alana ilişkin görüşlerini incelemek amacıyla yapılan bu araştırma nitel olarak tasarlanmıştır. Seggie ve Bayyurt'un (2015, s. 16) ifade ettiği gibi "Nitel araştırma, nicel araştırmaların aksine, gelişen ve değişen dünyanın ve oluşan yeni anlayışların ve beraberinde gelen sorun ve mücadelelerin detaylı bir şeklide anlaşılmasına olanak sağlar." Nitel araştırmalarda birtakım araştırma desenleri mevcuttur. Eylem araştırması, fenomenoloji, durum çalışması, etnografya, anlatı araştırması ve gömülü teori nitel araştırmaların desenlerindendir (Saban \& Ersoy, 2019). Bu araştırmanın deseni durum çalışmasıdır. 


\section{Çalışma Grubu}

Araştırmanın çalışma grubunu yabancı dil olarak Türkçe öğretimi ders kitabı yazarları teşkil etmektedir. Araştırma dâhilinde on üç yazarla görüşülmüştür. Yazarlara ait özellikler Tablo 1'de sunulmuştur:

Tablo 1.

Katılımciların Özellikleri

\begin{tabular}{ccc}
\hline Katılımcılar & Kıdem Y1lı & Eğitim Durumu \\
\hline 1. Yazar & 22 & Doktora \\
2. Yazar & 10 & Yüksek Lisans \\
3. Yazar & 11 & Yüksek Lisans \\
4. Yazar & 9 & Lisans \\
5. Yazar & 8 & Doktora \\
6. Yazar & 5 & Yüksek Lisans \\
7. Yazar & 11 & Yüksek Lisans \\
8. Yazar & 12 & Yüksek Lisans \\
9. Yazar & 8 & Yüksek Lisans \\
10. Yazar & 8 & Yüksek Lisans \\
11. Yazar & 9 & Yüksek Lisans \\
12. Yazar & 10 & Doktora \\
\hline
\end{tabular}

Tablo 1 katılımcılara ait bilgileri içermektedir. Katılımcıların kıdem yılı 5-22 yıl arasında değişmektedir. Sekiz katılımcı yüksek lisans, dört katılımcı doktora ve bir katılımcı lisans mezunudur. Ayrıca çalışma grubunu oluşturan yazarlar TÖMER'lerde aktif olarak ders verme tecrübesine sahiptir.

Araştırmanın katılımcı sayısı on üç ile sınırlandırılmıştır. Çünkü Yıldırım ve Şimşek' in (2008, s. 115) belirttiği üzere araştırmaya katılanlardan toplanacak verinin miktarı arttıkça örnekleme dâhil edilmesi gereken bireylerin sayısı azalmaktadır. $\mathrm{Bu}$ araştırmada ulaşılan veriler fazla olduğu için (bk. Verilerin Toplanması) belirtilen sayıda yazar ile görüşülmüştür. Araştırma için Akdeniz Üniversitesi Sosyal ve Beşeri Bilimler Bilimsel Araştırma ve Yayın Etiği Kurulundan gerekli etik kurul izni alınmıştır.

\section{Verilerin Toplanması}

Araştırmanın verileri yarı yapılandırılmış görüşme formu ile toplanmıştır. Literatürün taranmasıyla "müfredat", "beceriler", "dil bilgisi" ve "söz varlığı" temaları doğrultusunda sorular oluşturulmuştur. Bu sorulardan hareketle oluşturulan "Ders Kitabı Yazarlarının Görüşlerine Göre Yabancı Dil Olarak Türkçe Öğretimi” başlıklı form üç alan uzmanına gönderilmiştir. Ardından üç yazarla pilot uygulama yapılmıştır. Alan uzmanlarından gelen dönütler ile pilot uygulamalardan sonra yapılan düzenlemeler neticesinde görüşme sorularının son hâli ortaya çıkmıştır.

COVID-19 sebebiyle katılımcılarla yüz yüze görüşme gerçekleştirilememiştir. Görüşme, Zoom programıyla yapılmıştır. Görüşme sürelerine Tablo 2'de yer verilmiştir: 
Tablo 2.

Katılımcılarla Görüşme Süreleri

\begin{tabular}{ll}
\hline Katılımcılar & Görüşme Süreleri \\
\hline 1. Yazar & 44 dakika 12 saniye \\
2. Yazar & 47 dakika 28 saniye \\
3. Yazar & 51 dakika 38 saniye \\
4. Yazar & 28 dakika 34 saniye \\
5. Yazar & 44 dakika 3 saniye \\
6. Yazar & 39 dakika 39 saniye \\
7. Yazar & 38 dakika 32 saniye \\
8. Yazar & 34 dakika 41 saniye \\
9. Yazar & 30 dakika 20 saniye \\
10. Yazar & 38 dakika 53 saniye \\
11. Yazar & 39 dakika 56 saniye \\
12. Yazar & 52 dakika 49 saniye \\
13. Yazar & 42 dakika 11 saniye \\
\hline
\end{tabular}

Yazarlarla yapılan görüşme Microsoft Office Word programında Times New Roman yazı karakteri, 12 punto, 2,5 cm sayfa kenar boşlukları ve 1,5 satır aralığıyla yazıya aktarılmıştır. 117 sayfadan oluşan 44194 kelimelik veri elde edilmiştir.

\section{Verilerin Analizi}

Nitel olarak tasarlanmış araştırmalarda verileri analiz etmek için söylem analizi, betimsel analiz ve içerik analizi gibi tekniklerden yararlanılır. Bu araştırmada içerik analizi tekniği kullanılmıştır.

İçerik analizinde temel amaç, metinden elde edilen verileri açıklayabilecek kavram ve ilişkilere ulaşmaktır. Söz konusu kavramlar, araştırmacıyı temalara ulaştırır. Bu temalar sayesinde olgular düzenlenir ve anlaşılır hâle getirilir (Yıldırım \& Şimşek, 2008, s. 227). Ayrıca Büyüköztürk vd.nin (2008, s. 266) belirttiği gibi "Sayısallaştırma/sayma içerik analizinin önemli özelliklerinden biridir. Uygun kategoride yer alan her birim her seferinde sayılır. Kodlama sürecinin en son ürünü sayılar olmalıdır. Belli kelimelerin, ifadelerin, sembollerin, resimlerin kısacası açık olarak kodlanabilecek birimlerin sıklığının belirlenmesinde sayılar kullanılır."

Araştırmanın alt problem cümleleri, verilerin toplanmasına yön vermiştir. $\mathrm{Bu}$ nedenle araştırmada tümdengelimsel içerik analizine başvurulmuştur. Araştırmadaki temalar araştırma sürecinin başında belirlenmiştir. Araştırmanın kategori ve kodlarına analiz sürecinde ulaşılmıştır. Aşağıda araştırmanın tema ve kategorilerine yer verilmiştir:

Tablo 3.

Araştırmanın Tema ve Kategorileri

\begin{tabular}{cl}
\hline \multicolumn{1}{c}{ Temalar } & \multicolumn{1}{c}{ Kategoriler } \\
\hline \multirow{2}{*}{ Program } & Kitap yazımında kullanılan müfredat/müfredatlar \\
& İdeal bir müfredatın özellikleri \\
& Çeşitli kurumların birbirinden farklı müfredatlarının olması \\
& Dinleme/izleme becerisinin öğretimi \\
Konuşma becerisinin öğretimi & Okuma becerisinin öğretimi
\end{tabular}


Tablo 3'te görüldüğü üzere araştırmada 4 tema ve 9 kategori vardır. Katılımcılardan görüşme yoluyla elde edilen veriler birkaç defa okunarak kodlar çıkarılmıştır. Veri analizinin güvenirliliği için her iki araştırmacı ayrı ayrı kodlama yapmış ve kodlar arasında uyum olduğu görülmüştür. Bu uyumun tespitinde Miles ve Huberman (2015) formülünden yararlanılmıştır. Uyum yüzdesi ,87 olarak bulunmuştur. Bu uyumun \%70'ten yüksek olması gerektiği (Tavşancıl \& Aslan, 2001) için araştırmada yapılan içerik analizi güvenilir kabul edilmiştir.

Araştırmada ulaşılan tema, kategori ve kodlara "Bulgular" bölümünde tablolaştırılarak yer verilmiştir.

\section{Bulgular}

$\mathrm{Bu}$ bölümde araştırmanın alt problemlerinden hareketle ulaşılan bulgulara yer verilmiştir:

\section{Araştırmanın Birinci Alt Problemine İlişkin Bulgular}

Tablo 4.

Ders Kitabı Yazarlarının Yararlandiğı Müfredatlar

\begin{tabular}{llccc}
\hline No. & \multicolumn{1}{c}{ Esas Alınan Müfredat } & Yazarlar & f & $\%$ \\
\hline 1. & Diller İçin Avrupa Ortak Öneriler Çerçevesi & $1,2,3,4,5,6,8,10$, & 10 & $\% 76,92$ \\
2. & Türkiye Maarif Vakfı Yabancı Dil Olarak Türkçe & 12,13, & & \\
& Öğretim Programı & $8,9,10,11$ & 4 & $\% 30,76$ \\
3. & $\begin{array}{l}\text { Yunus Emre Enstitüsü Yabancı Dil Olarak Türkçe } \\
\text { Ögretim Programı }\end{array}$ & 9,10 & 2 & $\% 15,38$ \\
\hline
\end{tabular}

Tablo 4'te yazarların uluslararası öğrencilere ders kitabı yazım aşamasında yararlandıkları müfredatlara yer verilmiştir. En çok başvurulan müfredatın Diller İçin Avrupa Ortak Öneriler Çerçevesi (AOÖÇ) olduğu görülmektedir (f=10). Türkiye Maarif Vakfinca (TMV) hazırlanan 2019 Yabancı Dil Olarak Türkçe Öğretim Programı'nın (YDOTÖP-2019) (f=4) ve Yunus Emre Enstitüsüne ait müfredatının ( $\mathrm{f}=2$ ) AOÖÇ’yi takip ettiği anlaşılmaktadır.

\section{Araştırmanın İkinci Alt Problemine İlişkin Bulgular}

Tablo 5 .

Ders Kitabı Yazarlarının Görüşlerine Göre İdeal Bir Müfredatın Özellikleri

\begin{tabular}{|c|c|c|c|c|}
\hline No. & İdeal Bir Müfredatın Özellikleri & Yazarlar & $\mathrm{f}$ & $\%$ \\
\hline 1. & Öğrencilerin yaş düzeylerine uygun müfredat olmalıdır. & $1,6,7,8,12$ & 5 & $\% 38,46$ \\
\hline 2. & $\begin{array}{l}\text { Öğrencilerin dil öğrenme amaçlarına (ihtiyaçlarına) göre } \\
\text { farklı programlar olmalıdır. }\end{array}$ & $1,5,6,7,12$ & 5 & $\% 38,46$ \\
\hline 3. & Dört dil becerisini geliştiren bir program olmalıdır. & $2,4,5,11$ & 4 & $\% 30,76$ \\
\hline 4. & $\begin{array}{l}\text { Her kur seviyesinin altında beceriler ve becerilerin } \\
\text { yeterliliklerine (kazanımlarına) yer verilmelidir. }\end{array}$ & $8,10,13$ & 3 & $\% 23,07$ \\
\hline 5. & Becerilerle beraber dil bilgisi yapılarına da yer verilmelidir. & $2,3,13$ & 3 & $\% 23,07$ \\
\hline 6. & Seviyelere göre söz varlığı sıklıklarına yer vermelidir. & 8,13 & 2 & $\% 15,38$ \\
\hline 7. & Ölçme-değerlendirme açısından yol gösterici olmalıdır. & 5,10 & 2 & $\% 15,38$ \\
\hline 8. & $\begin{array}{l}\text { Öğrenci merkezli/öğrenciyi etkin kılan bir program } \\
\text { olmalıdır. }\end{array}$ & 10,11 & 2 & $\% 15,38$ \\
\hline 9. & $\begin{array}{l}\text { Öğrencilerin hazırbulunuşluklarına (kur seviyelerine) göre } \\
\text { ayrı ayrı tasarlanmış olmalıdır. }\end{array}$ & 1 & 1 & $\% 7,69$ \\
\hline
\end{tabular}


10. Strateji, yöntem ve teknik hususlarında yol gösterici olmalidir.

11. Öğrencilerin bir an önce konuşmasını sağlayacak bir program olmalidir.

12. Müfredatlar kurumdan kuruma değişmemelidir.

13. Müfredat, Türkçenin yurt içinde veya yurt dişında ögretilme durumuna göre hazırlanmalıdır.

14. Etkinlik örnekleri içermelidir.

\begin{tabular}{ccc}
10 & 1 & $\% 7,69$ \\
11 & 1 & $\% 7,69$ \\
7 & 1 & $\% 7,69$ \\
12 & 1 & $\% 7,69$ \\
9 & 1 & $\% 7,69$ \\
\hline
\end{tabular}

Tablo 5, "İdeal Bir Müfredatın Özellikleri” temasına ilişkin ulaşılan 14 farklı kodu göstermektedir. Öğrencilerin "yaş düzeyi” ve "dil öğrenme amaçları” ( $f=5)$ kodlarına eşit sıklıkta yer verilmiştir. Ardından sırasıyla "dört dil becerisini geliştirme" ( $\mathrm{f}=4)$, "kur seviyelerinin altında beceriler ve becerilerin yeterliliklerine (kazanımlarına) yer verme" ( $\mathrm{f}=3)$, "becerilerle beraber dil bilgisine yer verme" $(\mathrm{f}=3)$, "seviyelere göre söz varlığı sıklıklarına yer verme" ( $\mathrm{f}=2)$, "ölçmedeğerlendirmede yönlendirme" (f=2), "öğrenciyi etkin kılma" (f=2), öğrencilerin hazırbulunuşluk seviyelerini dikkate alma" (f=1), "strateji, yöntem ve tekniğe yer verme" ( $\mathrm{f}=1)$, "konuşma becerisini hızlıca geliştirme" ( $\mathrm{f}=1)$, "kurumlar arasında tek müfredat olması" ( $f=1)$, "yurt içinde/yurt dışındaki uluslararası öğrenciler için Türkçe öğretimine uygun müfredat" ( $\mathrm{f}=1$ ) ve "etkinlik örnekleri" ( $\mathrm{f}=1$ ) kodlarına ulaşılmıştır. Aşağıda yazar görüşlerinden örneklere yer verilmiştir:

Yetişkinler için, çocuklar için ayr programların olması gerektiğini düşünüyorum. Aynı zamanda üniversite okuyacak yetişkinler için ayrı, mesela Türkçeyi iş ortamında kullanacaklar için ayrı hani bir mesleki Türkçe programı ile genel Türkçe programının birbirinden ayrlması gerektiğinden yanayım. (1. Yazar)

Hedef kitle farklı ve Türkçeyi biz ikinci dil olarak mı ögretiyoruz, yabancı dil olarak mı ögretiyoruz? Yani bunun da iyi bilinmesi gerektiğini düşünüyorum. Dolaylsıyla hedef kitle ve Türkçenin nasıl bir ortamda ögretildiği Türkiye'de mi ögretiyoruz, yurtdışında mı ögretiyoruz? (12. Yazar)

\section{Araştırmanın Üçüncü Alt Problemine İlişkin Bulgular}

Tablo 6.

\section{Farklı Kurumlara Ait Müfredatların Olması}

\begin{tabular}{lllll}
\hline No. & \multicolumn{1}{c}{ Farklı Kurumlara Ait Müfredatlar Olması } & Yazarlar & f & $\%$ \\
\hline \multirow{2}{*}{. } & Farklı programlar olması öğrencilerin seviyelerinde kurumlar & $1,2,4,5,6$, & 7 & $\% 53,84$ \\
2. & arası farklılık doğurmaktadır. & 10,12 & & \\
3. & Ortak bir müfredat olmalıdır. & $1,2,6,7,9$ & 5 & $\% 38,46$ \\
Farklılı̆̆ın olması sorun oluşturmamaktadır/zenginliktir. & $3,4,8,11,13$ & 5 & $\% 38,46$ \\
4. & $\begin{array}{l}\text { Farklı müfredatlar olması tek merkezden sınav yapılmasını } \\
\text { engellemektedir. }\end{array}$ & 1 & 1 & $\% 7,69$ \\
\hline
\end{tabular}

Yukarıdaki tabloda farklı kurumlara/TÖMER'lere ait yabancı dil olarak Türkçe öğretimi müfredatının olması hakkında ders kitabı yazarlarının görüşleri yer almaktadır. En çok "farklı programların kurumlar arası farklılığa neden olduğu" (f=7) görüşü ifade edilmiştir. Eşit miktarda görüş ( $\mathrm{f}=5)$ birbirine zit biçimde "ortak bir müfredatın gerekliliği"ni ve "farklı müfredatların zenginlik olduğu"nu vurgulamaktadır. Bir yazar ise farklı müfredatların tek merkezden sınav yapılmasını engellediğini ifade etmiştir. Aşağıda yazar görüşlerinden örneklere yer verilmiştir: 
Biraz çok başlılık gibi olabiliyor gerçekten de. Gerçekten bir standart oluşmalı bence. Türkçenin kurallar okuldan okula, kurumdan kuruma değişmiyor. Kaynaktan kaynă̆a değişmiyor. Kuralları belli, yazımı belli, grameri belli. (7. Yazar)

Program tek olmadı̆̆ için birliktelik sağlanamıyor. Ortak bir program olmadığ için elimizde kitaplar farklılaşıyor, ders işleme teknikleri farklılaşıyor, yetişen ögrenci bile farklılaşlyor. (10. Yazar)

\section{Araştırmanın Dördüncü Alt Problemine İlişkin Bulgular}

Tablo 7.

Ders Kitabı Yazarlarının Dinleme Becerisinin Öğretimi Hakkındaki Görüşleri

\begin{tabular}{|c|c|c|c|c|}
\hline No. & Dinleme Becerisinin Öğretimi & Yazarlar & $\mathrm{f}$ & $\%$ \\
\hline 1. & Dinleme öncesi, sırası ve sonrası etkinlikler olmalıdır. & $\begin{array}{c}1,2,4,5,6,7,8 \\
13\end{array}$ & 8 & $\% 61,53$ \\
\hline 2. & $\begin{array}{l}\text { Günlük yaşamla ilgili (doğal) dinleme metinlerine yer } \\
\text { verilmelidir. }\end{array}$ & $5,6,7,10,11,12$ & 6 & $\% 46,15$ \\
\hline 3. & Dinleme metinleri kaliteli biçimde seslendirilmelidir. & $1,6,8,10$ & 4 & $\% 30,76$ \\
\hline 4. & Dinleme etkinlikleri kısa cevaplı sorulardan oluşmalıdır. & $1,2,8$ & 3 & $\% 23,07$ \\
\hline 5. & $\begin{array}{l}\text { Dinleme metinleri günlük hayata yakın biçimde } \\
\text { seslendirilmelidir. }\end{array}$ & $5,7,8$ & 3 & $\% 23,07$ \\
\hline 6. & Dinlemenin yanı sıra izlemeye de yer verilmelidir. & 1,3 & 2 & $\% 15,38$ \\
\hline 7. & Uygun bir ortam (mekân, teknik araçlar) olmalıdır. & 11,13 & 2 & $\% 15,38$ \\
\hline 8. & $\begin{array}{l}\text { Dinleme metinlerinin kelime sayıları seviyelere göre } \\
\text { belirlenmelidir. }\end{array}$ & 1 & 1 & $\% 7,69$ \\
\hline 9. & $\begin{array}{l}\text { Öğrenciler dinleme metinlerinden hareketle bir şeyler } \\
\text { üretebilmelidir. }\end{array}$ & 10 & 1 & $\% 7,69$ \\
\hline 10. & $\begin{array}{l}\text { Günlük hayatta sık kullanılan kelimeleri içeren dinleme } \\
\text { metinleri olmalıdır. }\end{array}$ & 11 & 1 & $\% 7,69$ \\
\hline 11. & $\begin{array}{l}\text { Dinleme metinlerinde öğrencilerin bilmediği kelimelere çok } \\
\text { fazla yer verilmemelidir. }\end{array}$ & 11 & 1 & $\% 7,69$ \\
\hline 12. & $\begin{array}{l}\text { Dinleme becerisi, ögretmenin dinlenilmesi esasına dayanarak } \\
\text { yapılmalıdır. }\end{array}$ & 12 & 1 & $\% 7,69$ \\
\hline 13. & $\begin{array}{l}\text { Diğer becerilerde kullanılan kelime kadrosunu tekrar etmeye } \\
\text { dayalı dinleme becerisi öğretimi yapılmalıdır. }\end{array}$ & 13 & 1 & $\% 7,69$ \\
\hline 14. & Dinleme metinleri kısa olmalıdır. & 13 & 1 & $\% 7,69$ \\
\hline 15. & $\begin{array}{l}\text { Dinleme becerisiyle birlikte not alma teknikleri de } \\
\text { öğretilmelidir. }\end{array}$ & 5 & 1 & $\% 7,69$ \\
\hline 16. & $\begin{array}{l}\text { Dinleme/izleme metinleri ve etkinlikleri kazanım odaklı } \\
\text { olmalıdır. }\end{array}$ & 13 & 1 & $\% 7,69$ \\
\hline
\end{tabular}

Verilen tabloda yazarların dinleme becerisinin öğretimine yönelik görüşleri yer almaktadır. Sekiz yazar dinleme öncesi, sırası ve sonrası etkinlikler olarak bilinen dinleme stratejilerinin olması gerektiğini ifade etmiştir. Altı yazar ise dinleme metinlerinin günlük yaşamla ilgili olması gerektiğini belirtmiştir. Dinleme metinlerinin kaliteli seslendirilmesini dört yazar dile getirmiştir. Üçer yazar etkinliklerin kısa cevaplı olmasını ve metin seslendirmesinin günlük hayata uygun olmasını ifade etmiştir. "Dinlemenin yanı sıra izlemeye yer verilmesi" ( $f=2)$, "dinleme için uygun ortamın olması" ( $\mathrm{f}=2)$, "dinleme metinlerinin kelime sayılarının seviyelere göre belirlenmesi" ( $\mathrm{f}=1$ ), "dinleme metinlerinin öğrencileri üretmeye yönlendirmesi" ( $\mathrm{f}=1)$, "metinlerin günlük hayatta sık kullanılan kelimeleri içermesi" $(\mathrm{f}=1)$, "metinlerin bilinmeyen kelimelere çok yer vermemesi" ( $\mathrm{f}=1$ ), "dinleme metinlerini öğretmenin seslendirmesi" ( $\mathrm{f}=1)$, "diğer becerilerde öğrenilen kelime kadrosunu tekrar etmesi” ( $\mathrm{f}=1)$, "metinlerin k1sa olması" ( $\mathrm{f}=1)$, "not alma 
tekniklerinin öğretilmesi" ( $\mathrm{f}=1)$, "metin ve etkinliklerin kazanım odaklı olması" $(\mathrm{f}=1)$ ders kitabı yazarlarının görüşlerinden ulaşılan diğer verilerdir. Aşağıda yazar görüşlerinden örneklere yer verilmiştir:

Bir metin hâlinde önümüze gelen metni seslendirirken konuşma dilinde ana dili konuşurlart nasll telaffuz ediyorsa öyle edilmesi gerektiğini düşünüyorum. 'Gelecĕgim, yapacă̆ım' değil de 'gelicem, yapıcam' şeklinde telaffuz edilmeli. Doğal metnin oluşturulmasinda da sunulmasinda da doğal anadili konuşuru gibi sunulmasından yanayım. Bu çok önemli bence. Çünkü sınıfin dışındaki hayatına yardımcı olmaya, hizmet etmeye çalışlyorsak oradaki gibi sunmallyı bence bir materyalimizi. (7. Yazar)

Dinleme becerisini gerçekleştirirken öğrencilerin dikkatli olmalarını ortamın sessizliğinin ögretmen tarafindan ayarlanmasının gerektiğini düşünüyorum. Ĕger ortamda normal dinlemenin haricinde farkll sesler bulunursa bu dinlemeyi etkileyecek. Aynı zamanda dinlemeyi etkilediği için ögrrenmeyi de etkileyecektir. (11. Yazar)

Seslendirme yapacak insanların doğal, akıcl, hani otantik olmasl çok önemli. Çünkü hani biz dinlemeleri verdik ses kayıtlarl geldi, bakıyoruz robotik bir konuşma var. Biz Türkçede böyle robotik bir konuşmayla ögrencilere Türkçe ögretmiyoruz ya da böyle bir Türkçeyle hiçbir yerde karşllaşmayacaklar. (13. Yazar)

\section{Araştırmanın Beşinci Alt Problemine İlişkin Bulgular}

Tablo 8.

Ders Kitabı Yazarlarının Konuşma Becerisinin Öğretimi Hakkındaki Görüşleri

\begin{tabular}{|c|c|c|c|c|}
\hline No. & Konuşma Becerisinin Öğretimi & Yazarlar & f & \\
\hline 1. & $\begin{array}{l}\text { Konuşma etkinliklerinde yönergeler (alt sorular) } \\
\text { olmalıdır. }\end{array}$ & $\begin{array}{l}1,2,5,6,8 \\
9,12,13\end{array}$ & 8 & $\% 61,53$ \\
\hline 2. & Konuşma stratejilerine yer verilmelidir. & $\begin{array}{c}1,5,6,7,8 \\
11,12,13\end{array}$ & 8 & $\% 61,53$ \\
\hline 3. & $\begin{array}{l}\text { Sözlü anlatımın yanı sıra karşılıklı konuşma etkinliklerine } \\
\text { de yer verilmelidir. }\end{array}$ & $\begin{array}{c}1,2,4,6,8 \\
13\end{array}$ & 6 & $\% 46,15$ \\
\hline 4. & $\begin{array}{l}\text { Konuşma becerisi etkinliklerinde grup çalışmalarına da } \\
\text { yer verilmelidir. }\end{array}$ & $3,7,8,13$ & 4 & $\% 30,76$ \\
\hline 5. & $\begin{array}{l}\text { Dinleme, konuşma ve yazmaya bir arada (bütünleşik } \\
\text { beceri) yer verilmelidir. }\end{array}$ & $1,4,13$ & 3 & $\% 23,07$ \\
\hline 6. & $\begin{array}{l}\text { Konuşma etkinlikleri ders kitabındaki temayla ilgili } \\
\text { olmalıdır. }\end{array}$ & $3,5,10$ & 3 & $\% 23,07$ \\
\hline 7. & $\begin{array}{l}\text { Öğrencinin ilgisini çekebilecek, yaş ve seviyesine uygun } \\
\text { günlük hayatla ilgili konuşma konularına yer verilmelidir. }\end{array}$ & $4,10,13$ & 3 & $\% 23,07$ \\
\hline 8. & Öğretmenin hazırlıklı ve örnek olması gerekmektedir. & $7,11,12$ & 3 & $\% 23,07$ \\
\hline 9. & $\begin{array}{l}\text { Konuşma etkinliklerinde öğrenci hassasiyetlerine dikkat } \\
\text { edilmelidir. }\end{array}$ & 2,13 & 2 & $\% 15,38$ \\
\hline 10. & $\begin{array}{l}\text { Konuşma etkinliklerinde öğrencilerin bildikleri kelime } \\
\text { kadrosundan hareket edilmelidir. }\end{array}$ & 7,13 & 2 & $\% 15,38$ \\
\hline 11. & $\begin{array}{l}\text { Sınıf içi uygulamada konuşma becerisine diğer becerilere } \\
\text { göre az yer verilmemelidir. }\end{array}$ & 11 & 1 & $\% 7,69$ \\
\hline 12. & $\begin{array}{l}\text { Öğrencinin konuşma yanlışları uygun biçimde } \\
\text { düzeltilmelidir. }\end{array}$ & 11 & 1 & $\% 7,69$ \\
\hline 13. & $\begin{array}{l}\text { Konuşma etkinlikleri dil bilgisi yapılarını tekrar amaçlı } \\
\text { içermelidir. }\end{array}$ & 6 & 1 & $\% 7,69$ \\
\hline 14. & Konuşma etkinlikleri kültürel etkileşime uygun olmalıdır. & 6 & 1 & $\% 7,69$ \\
\hline 15. & Telaffuz öğretimine yer verilmelidir. & 9 & 1 & $\% 7,69$ \\
\hline
\end{tabular}


Tablo 8, yazarların konuşma becerisi öğretimine ilişkin görüşlerini içermektedir. En çok ifade edilen görüş sekizer sıklıkla "konuşma etkinliklerinde yönergelerin olması" ve konuşma stratejilerine yer verilmesi”dir. Bu iki kodu sırasıyla "sözlü anlatımın yanında karşılıklı konuşmaya da yer verilmesi” ( $\mathrm{f}=6)$, "grup çalışmasına yer verilmesi" ( $f=4)$, "bütünleşik beceri öğretimi yapılması" ( $f=3)$, "konuşma etkinliklerinin temayla ilgili olması" ( $\mathrm{f}=3$ ), "ilgi çekici ve seviyeye uygun günlük hayat uygulamalarının yapılması" ( $\mathrm{f}=3)$, "öğretmenin hazırlıklı ve örnek olması" $(\mathrm{f}=3)$, "konuşma etkinliklerinde öğrenci hassasiyetlerine dikkat edilmesi (örneğin ailesi hakkında konuşmasının istenmemesi)" ( $\mathrm{f}=2)$, "öğrencinin bildiği kelime kadrosundan hareket edilmesi" ( $\mathrm{f}=2)$, "konuşma etkinliklerinin diğer becerilerden az olmaması" ( $\mathrm{f}=1)$, "konuşma yanlışlarının uygun biçimde düzeltilmesi” ( $\mathrm{f}=1)$, "dil bilgisi yapılarını tekrar amaçlı içermesi" ( $\mathrm{f}=1)$, "kültürel etkileşime uygun olması" $(\mathrm{f}=1)$ ve "telaffuz öğretimine yer vermesi" $(\mathrm{f}=1)$ görüşleri takip etmiştir. Aşağıda yazar görüşlerinden örneklere yer verilmiştir:

Kitaptaki tema neyse öğrencileri de sinıfta konuşturacaksak buna yönelik bir soru sormamı gerekiyor. (5. Yazar)

Öğrenciye durum veriyoruz, bu duruma yönelik ikişerli veya üçerli gruplar hâlinde konuşmasını istiyoruz. Hazırlı yapıyorlar ve bu hazırlı̆̆a göre bir konuşma yapıyorlar veya bir tartışma yapabiliyorlar. Münazara yapabiliyorlar. Mesela bir garson diyaloğu veya hasta doktor diyaloğu veriyoruz. Biriniz hasta biriniz doktor olsun, diyoruz. (8. Yazar)

Bir öğrencinin kültürel bakış açısını, yaşayış tarzını hani din, dil, ırk ayrımı yapmadan onların hassasiyetini incitmeden konuşma etkinlikleri yapılmall. Etkinlikler siyasi olmamal, dini içerikli olmamal. Önce buna dikkat etmemiz lazım. Bazen de oluyor işte ailesi ile ilgili konuşmasını istiyoruz ama annesi yok, babası yok gibi. (13. Yazar)

\section{Araștırmanın Altıncı Alt Problemine İlișkin Bulgular}

Tablo 9.

Ders Kitabı Yazarlarının Okuma Becerisinin Öğretimi Hakkındaki Görüşleri

\begin{tabular}{|c|c|c|c|c|}
\hline No. & Okuma Becerisinin Öğretimi & Yazarlar & $\mathrm{f}$ & $\%$ \\
\hline 1. & Okuma stratejilerine yer verilmelidir. & $\begin{array}{l}1,2,3,4,5,6 \\
7,8,11,12,13\end{array}$ & 11 & $\% 84,61$ \\
\hline 2. & Okuma metinleri kur seviyelerine ve yaşa uygun olmalıdır. & $1,8,9,10$ & 4 & $\% 30,76$ \\
\hline 3. & Öğrencilerin grafik ve tablo okumaları da sağlanmalıdır. & $1,2,6,13$ & 4 & $\% 30,76$ \\
\hline 4. & $\begin{array}{l}\text { Okuma metinleri öğrenciyi konuşturmaya ve yazmaya } \\
\text { (bütünleşik beceri) imkân vermelidir. }\end{array}$ & $1,7,8$ & 3 & $\% 23,07$ \\
\hline 5. & Doğal (otantik) metinlere de yer verilmelidir. & $7,10,12$, & 3 & $\% 23,07$ \\
\hline 6. & $\begin{array}{l}\text { Temayı, dil bilgisi yapısını ve sözcükleri bir arada } \\
\text { barındıracak metinlere yer verilmelidir. }\end{array}$ & $2,6,9$ & 3 & $\% 23,07$ \\
\hline 7. & $\begin{array}{l}\text { Okuma metinlerinde öğretilmeyen dil bilgisi yapıları } \\
\text { olmamalıdır. }\end{array}$ & $5,6,8$ & 3 & $\% 23,07$ \\
\hline 8. & $\begin{array}{l}\text { Metin altı soruları ögrencilerin yorum yapmasına da imkân } \\
\text { vermelidir. }\end{array}$ & 1,8 & 2 & $\% 15,38$ \\
\hline 9. & $\begin{array}{l}\text { Okuma metinlerinde öğrencinin bilmediği kelime sayısı } \\
\text { çok olmamalıdır. }\end{array}$ & 1 & 1 & $\% 7,69$ \\
\hline 10. & $\begin{array}{l}\text { Okuma metninin konusuna uygun kelime kadrosu da } \\
\text { verilmelidir. }\end{array}$ & 12 & 1 & $\% 7,69$ \\
\hline 11. & $\begin{array}{l}\text { Temel seviyede günlük hayatta karşılaşılan uyarı levhaları, } \\
\text { yönergeler okuma metni olarak kullanılmalıdır. }\end{array}$ & 13 & 1 & $\% 7,69$ \\
\hline
\end{tabular}


12. Okuma metinleri telaffuz amaçlı farklı öğrencilere

okutulmalıdır.

$13 \quad 1 \quad \% 7,69$

13. Okuma metinleri sınıf içi etkileşime uygun olmalıdır.

$3 \quad 1 \quad \% 7,69$

Tablo 9'da okuma becerisinin öğretimi hakkında ders kitabı yazarlarının görüşleri yer almaktadır. "Okuma stratejilerine yer verilmesi" ( $\mathrm{f}=11)$ en çok ifade edilen görüştür. Dörder yazar "metinlerin kur seviyelerine/yaşa uygunluğu”nu ve "grafik/tablo okumanın gerekliliği’ni belirtmiştir. "Bütünleşik beceri öğretimi”" $(\mathrm{f}=3)$, "doğal metinlere yer verilmesi" ( $\mathrm{f}=3$ ), "tema, dil bilgisi ve uygun söz varlığını içeren metinlerin olması" ( $\mathrm{f}=3)$, "metinlerde öğretilmeyen dil bilgisi yapılarının olmaması" ( $\mathrm{f}=3)$, "metin altı sorularının yorum yapmaya uygun olması" ( $\mathrm{f}=2)$, "metinlerde bilinmeyen kelime sayısının çok olmaması" ( $\mathrm{f}=1)$, "metinlere uygun kelime kadrosunun da öğrencilere sunulması" ( $\mathrm{f}=1)$, "günlük hayatta karşılaşılan levha ve yönergelere yer verilmesi" ( $\mathrm{f}=1)$, "metinlerin telaffuz amaçlı öğrencilere okutulması" ( $\mathrm{f}=1)$ ve "metinlerin sınıf içi etkileşime uygun olması" ( $\mathrm{f}=1$ ) yazarların ifade ettiği diğer görüşlerdir. Aşağıda yazar görüşlerinden örneklere yer verilmiştir:

Özellikle bizim kitabımızda biz ögretmediğimiz bir gramerin okuma metinlerinde yer almasını çok doğru bulmadık. (5. Yazar)

Okuma metinlerinde bilimsel verilerden faydalanmaya çalıştı. İşte okuma metinlerinde grafik okunmasını sağladı̆̆ımı bazı etkinlikler yaptık. Tablolar okumasını istedik ya da işte bir tabloyu, bir okuma metnindeki bilgileri tabloya dökmesini sağladık. (6. Yazar)

Özellikle ilk önce okuma öncesi okuma sırası okuma sonrası etkinliklerimiz oldu. (8. Yazar)

İdeal okuma ögretimi ögrrencinin ihtiyaçlarına, ögrenme alışkanlıklarına ve bireysel özelliklerine dikkat edilerek oluşturulmalıdır, diye düşünüyorum. (9. Yazar)

\section{Araştırmanın Yedinci Alt Problemine İlişkin Bulgular}

Tablo 10.

Ders Kitabı Yazarlarının Yazma Becerisinin Öğretimi Hakkındaki Görüşleri

\begin{tabular}{|c|c|c|c|c|}
\hline No. & Yazma Becerisinin Öğretimi & Yazarlar & $\mathrm{f}$ & $\%$ \\
\hline 1. & $\begin{array}{l}\text { Yazma becerisi dinleme, konuşma ve okuma becerileriyle } \\
\text { bütünleşik olmalıdır. }\end{array}$ & $\begin{array}{l}1,2,5,12, \\
13\end{array}$ & 5 & $\% 38,46$ \\
\hline 2. & $\begin{array}{l}\text { Yazma etkinlikleri yönergeler (yönlendirici alt sorular) } \\
\text { içermelidir. }\end{array}$ & $1,3,8,9$ & 4 & $\% 30,76$ \\
\hline 3. & Yazma görevleri öncesinde örnekler verilmelidir. & $2,4,6$ & 3 & $\% 23,07$ \\
\hline 4. & Süreç temelli yazmaya yer verilmelidir. & $6,8,9$ & 3 & $\% 23,07$ \\
\hline 5. & İş birlikli yazma etkinlikleri yapılmalıdır. & 1,8 & 2 & $\% 15,38$ \\
\hline 6. & Günlük yaşamla ilgili olabilecek yazma görevleri olmalıdır. & 4,10 & 2 & $\% 15,38$ \\
\hline 7. & $\begin{array}{l}\text { Öğrencinin yazma ödevi öğretmen tarafindan kontrol edilip } \\
\text { öğrenciye geri bildirim verilmelidir. }\end{array}$ & 11,12 & 2 & $\% 15,38$ \\
\hline 8. & Yazma etkinlikleri dil bilgisi yapılarını da içermelidir. & 8,13 & 2 & $\% 15,38$ \\
\hline 9. & $\begin{array}{l}\text { Yazma becerisi etkinlikleri öğrencileri akademik yazmaya } \\
\text { yönlendirmelidir. }\end{array}$ & 2,8 & 2 & $\% 15,38$ \\
\hline 10. & İmla ve noktalama öğretimi de yapılmalıdır. & 10 & 1 & $\% 7,69$ \\
\hline 11. & Ürün odaklı yazmaya yönelik ev ödevleri verilmelidir. & 12 & 1 & $\% 7,69$ \\
\hline 12. & Öğrencilerin yazı örnekleri sınıf ortamında sergilenmelidir. & 12 & 1 & $\% 7,69$ \\
\hline 13. & Yazma becerisi öğretimi için ayrı bir ders kitabı olmalıdır. & 13 & 1 & $\% 7,69$ \\
\hline 14. & $\begin{array}{l}\text { Öğrencilere metni oluşturan paragrafları ve paragrafların } \\
\text { içeriğini planlama becerisi öğretilmelidir. }\end{array}$ & 2 & 1 & $\% 7,69$ \\
\hline 15. & Yazma stratejileri kullanılmalıdır. & 6 & 1 & $\% 7,69$ \\
\hline
\end{tabular}


16. Yazma etkinlikleri öğrencinin Türkçe öğrenme amacına uygun $\quad 7 \quad 1 \quad \% 7,69$ olmalıdır.

17. Öğrenciler, farklı metin türlerini yazmaya yönlendirilmelidir. $\quad 8$

$1 \% 7,69$

Yukarıdaki tabloda yazarların yazma becerisinin öğretimine ilişkin görüşleri sunulmuştur. Beş yazar yazma becerisinin diğer becerilerle bütünleşik olarak öğretilmesi gerektiğini ifade etmiştir. Dört yazar, yazma etkinliklerinde yönlendirici alt sorulara ihtiyaç olduğunu belirtmiştir. Üçer yazar ise "yazma görevlerinden önce örneklerin verilmesi"ni ve "süreç temelli yazma modelinin uygulanması"nı vurgulamıştır. İkişer yazar, "iş birlikli yazma etkinliklerinin yapılması"nı, "günlük yaşamla ilgili yazma görevlerinin olması”nı, “öğretmenin öğrenciye geri bildirim vermesi"ni, "yazma etkinliklerinin dil bilgisi yapılarını içermesi”ni ve "yazma etkinliklerinin akademik yazmaya yönlendirmesi”ni dile getirmiştir. Ardından "imla ve noktalama öğretimi” ( $\mathrm{f}=1)$, "ev ödevlerinin verilmesi” $(\mathrm{f}=1)$, "yazı örneklerinin sınıfta sergilenmesi”" ( $f=1)$, "yazma becerisi için ayrı bir ders kitabının olması" $(\mathrm{f}=1)$, "paragrafların planlanmasının öğretilmesi” ( $\mathrm{f}=1)$, "yazma stratejilerinin kullanılması" (f=1), "yazma etkinliklerinin Türkçe öğrenme amacına uygun olması" ve "farklı metin türlerinin yazdırılması" görüşleri ifade edilmiştir. Aşağıda yazar görüşlerinden örneklere yer verilmiştir:

Yazmada da tıpk konuşmada olduğu gibi öğrenciye bir konu verip işte "Bu konuda haydi şunu yazın." biçiminde bir yönerge vermedik. Neler yazmaları gerektiğinden özellikle bahsettik. Diyelim ki işte bir şikâyet dilekçesi yazacak. Onunla ilgili ögrrenciye dedik ki "Durumu anlat, şikâyetini söyle, çözüm önerisi sun ve bunu iste." biçiminde hani örnek veriyorum. Ne yazmast gerektiğini belirttik. (1. Yazar)

Yazma için özellikle şunu yapmaya çalıştık dinleme artı yazma, konuşma artı yazma, okuma artı yazma gibi asıl konuşma içinde bunu yapmaya çalıştı. Zaman zaman dinleme metinlerinde de yaptı yani farklı becerileri birbirine bağlama... (2. Yazar)

Belirli bir sürede süreç odakl yazmalar olmall. Sadece o seviye için değil bütün ögrenim süreci için Al'den Cl'e kadar bir süreç olmalı diye düşünüyorum. (6. Yazar)

\section{Araştırmanın Sekizinci Alt Problemine İlişsin Bulgular}

Tablo 11.

Ders Kitabı Yazarlarının Dil Bilgisi Öğretimi Hakkındaki Görüşleri

\begin{tabular}{clccc}
\hline No & \multicolumn{1}{c}{ Dil Bilgisi } & Yazarlar & f & $\%$ \\
\hline 1 & Doğrudan dil bilgisi öğretimi yapılmalıdır. & $1,2,4,5,6,7,8,10$, & 10 & $\% 76,92$ \\
2 & $\begin{array}{l}\text { Dil bilgisi öğretimi metin ve becerilerden bağımsız } \\
\text { olarak yapılmamalıdır. }\end{array}$ & $1,2,3,4,6,10,11$, & 8 & $\% 61,53$ \\
3 & $\begin{array}{l}\text { Öğrenciler dil bilgisi kurallarını görünce } \\
\text { olmaktadır. }\end{array}$ & 13 & & \\
4 & İşlevsel dil bilgisi öğretimi yapılmalıdır. & $3,6,9,10,12$ & 5 & $\% 38,46$ \\
\end{tabular}

Tablo 11'de yazarların uluslararası öğrencilere Türkçe dil bilgisi öğretimine ilişkin görüşleri yer almaktadır. On yazar dil bilgisi konularını doğrudan öğretmenin gerekli olduğunu vurgulamıştır. Sekiz yazar da dil bilgisi öğretiminin dil becerileri 
ve metinlerden ayrı olmaması gerektiğini ifade etmiştir. Birinci ve ikinci görüşü savunanlar arasında altı yazar ortaktır $(1,2,4,6,10$ ve 13. yazarlar). Belirtilen altı yazar, beceriler ve metinlerden hareketle yeri geldiğinde dil bilgisi konusunun ayrıca anlatılması taraftarıdır. Bu yazarları destekleyecek biçimde beş yazar da öğrencilerin dil bilgisi kurallarını görünce motive olduklarını ifade etmiştir. Bir yazar ise işlevsel dil bilgisi öğretiminin yapılmasını dile getirmiştir. Aşağıda yazar görüşlerinden örneklere yer verilmiştir:

Dolayıslyla dil bilgisi ögretiminin yapılmasından yanayım ama dil bilgisi ögretimi kesinlikle metinden bağımsız olarak yapılmamalı. (1. Yazar)

Dil bilgisi ögrretiminin gerekli olduğunun düşünen biriyim... Temadan bağlamdan işlevden hareketle bir dil bilgisi ögretimi gerçekleştirmeliyiz. (10. Yazar)

Dil bilgisi çevirisinden ziyade daha çok yine işine yarayabilecek işlevleri vererek ögrenciye dil bilgisi ögretmeliyiz. (10. Yazar)

Yani ögrenci kuralı gördüğ̈̈ zaman mutlu oluyor. Elinde bir formül var. Ben bu kurall/formülü bildiğim zaman bunu yapabileceğim, diye düşünüyor. (12. Yazar)

\section{Araştırmanın Dokuzuncu Alt Problemine İlişkin Bulgular}

Tablo 12.

Ders Kitabı Yazarlarının Söz Varlı̆̆ı Öğretimi Hakkındaki Görüşleri

\begin{tabular}{|c|c|c|c|c|}
\hline No. & Söz Varlığı & Yazarlar & $\mathrm{f}$ & $\%$ \\
\hline 1. & $\begin{array}{l}\text { Bağlamdan hareketle tahmin etme stratejisi } \\
\text { kullanılmalıdır. }\end{array}$ & $\begin{array}{l}1,2,3,4,6,8 \\
9,10,11,12,13\end{array}$ & 11 & $\% 84,61$ \\
\hline 2. & $\begin{array}{l}\text { Kur seviyelerine ve temalara göre söz varlığı listeleri } \\
\text { olmalıdır. }\end{array}$ & $1,2,5,6,7,8$ & 6 & $\% 46,15$ \\
\hline 3. & $\begin{array}{l}\text { Dil becerilerinin öğretimi içinde söz varlığı öğretimine } \\
\text { yer verilmelidir. }\end{array}$ & $2,8,11,12,13$ & 5 & $\% 38,46$ \\
\hline 4. & Çeşitli söz varlığı öğretimi stratejileri kullanılabilir. & $1,2,5,6,10$ & 5 & $\% 38,46$ \\
\hline 5 . & $\begin{array}{l}\text { Yeni öğrenilen söz varlığından hareketle öğrenciden } \\
\text { yazma veya konuşma metni üretmesi istenmelidir. }\end{array}$ & $9,12,13$ & 3 & $\% 23,07$ \\
\hline 6. & $\begin{array}{l}\text { Söz varlığ́ öğretimi öğrencinin günlük hayatında sıklıkla } \\
\text { karşılaşabileceği kelimelerden hareketle yapılmalıdır. }\end{array}$ & 11,12 & 2 & $\% 15,38$ \\
\hline 7. & $\begin{array}{l}\text { Söz varlığı öğretiminde görsellerden de destek } \\
\text { alınmalıdır. }\end{array}$ & 9,13 & 2 & $\% 15,38$ \\
\hline 8. & $\begin{array}{l}\text { Alfabe öğretimi yapılırken söz varlığı öğretimi de } \\
\text { yapılmalıdır. }\end{array}$ & 11 & 1 & $\% 7,69$ \\
\hline 9. & $\begin{array}{l}\text { Söz varlı̆̆ı öğretimi ayrı bir ders saatinde müstakil olarak } \\
\text { yapılmalıdır. }\end{array}$ & 4 & 1 & $\% 7,69$ \\
\hline 10. & Temel seviyede kelime defteri tutturulmalıdır. & 12 & 1 & $\% 7,69$ \\
\hline
\end{tabular}

Ders kitabı yazarlarının söz varlığı öğretimi hakkındaki görüşleri Tablo 12'de sunulmuştur. Yazarların çoğu "bağlamdan hareketle kelime anlamını bulma" stratejisinin kullanılmasını önermiştir ( $\mathrm{f}=11)$. Altı yazar kur seviyelerine ve temalara göre söz varlığı listelerinin olması gerektiğini ifade etmiştir. Beşer yazar, "söz varlığı öğretiminin beceri öğretimine dâhil edilmesi”ni ve "çeşitli söz varlığ stratejilerinin kullanılabileceği”ni vurgulamıştır. Ardından "yeni öğrenilen söz varlığının yazma ve konuşma görevlerinde kullanılması" ( $\mathrm{f=3}$ ), "günlük hayatta sıklıkla karşılaşılan kelimelere yer verilmesi" ( $\mathrm{f}=2)$, "görsellerden destek alınması" $(\mathrm{f}=2)$, "alfabe öğretiminde de söz varlığ öğretilmesi” ( $\mathrm{f}=1)$, "söz varlığı öğretiminin 
ayrı bir derste yapılması" ( $\mathrm{f}=1)$ ve "temel seviyede kelime defteri tutulması" ( $\mathrm{f}=1)$ görüşlerine yer verilmiştir. Aşağıda yazar görüşlerinden örneklere yer verilmiştir:

Kesinlikle sözcük ögretimi bağlamla yapılmalı. Yani, bağlam dışında sözcük ögretimi çok nadiren işe yarlyor. (2. Yazar)

Öncelikle kelimeleri görsellerle, ögretip daha sonra bağlamlar içinde sunup, daha sonra kendilerinin işte o konuyla ilgili o kelimeleri kullanarak birtakım uygulama yapabilecekleri etkinlikler hazırllyoruz. (9. Yazar)

Dört temel dil becerisi içerisinde bu kelime öğretimine sözcük öğretimine yer vermemiz gerekiyor diye düşünüyorum. (11. Yazar)

Kelime defterleri tutmaların isteriz yani bunun dediğim gibi temel düzeylerde çok önemseriz hem sesletim açısından elinizde olsun bir defter çünkü hala harf ögretiminde özellikle Arap harfli yahut Latin harfleri bile olsa sesletimde farklıliklar oluyor öyle bir defterin tabi ki faydalı olacağı ilk başlangıçta temel düzeylerde önem arz ettiğini söylüyoruz onlara ama en önemlisi burada yine bă̆lamdan ögrenmeleri. (12. Yazar)

\section{Tartışma, Sonuç ve Öneriler}

Araştırmanın birinci alt bulgusunda yazarların en çok AOÖÇ ve TMV'ye başvurdukları görülmüştür. AOÖÇ’nin dil öğretimi çalışmalarına 2001 yılından beri (Fişekçioğlu, 2020) yön vermesi, bu sonucu anlaşılır kılmaktadır. Ayrıca TMV'nin ilk olarak 2019'da yayımlanmasına rağmen bazı yazarlar tarafından kitap yazımında dikkate alınması, yabancı dil olarak Türkçe öğretiminde güncel gelişmelere göre hazırlanan, alan uzmanlarınca yazılmış kapsamlı bir müfredat ihtiyacına karşılık olarak ortaya konulmasıyla açıklanabilir. Nitekim TMV'ye yönelik yapılan bazı araştırmalar bu tespite örnek gösterilebilir (Balcı \& Melanlıŏlu, 2020; Karagöl, 2020a; Kaya \& Kardaş, 2020). Araştırmanın birinci alt bulgusu ve literatürde yapılan çalışmalar dikkate alındığında yazarların yabancı dil olarak Türkçe öğretimi alanında kurumsal ve kamuya açık (yayımlanmış) müfredatlardan kitap yazım sürecinde faydalandığı sonucuna ulaşılabilir.

Araştırmanın ikinci alt probleminde yazarlar ideal bir yabancı dil olarak Türkçe öğretimi müfredatını tarif etmiştir. En çok verilen ortak cevaplara göre ideal bir müfredat öğrencilerin yaş düzeylerini ve Türkçe öğrenme amaçlarını dikkate almalıdır. Ayrıca müfredat dil becerilerini geliştirme, kur seviyelerine göre kazanımların tanımlanması, dil bilgisi yapılarının verilmesi, söz varlığı sıklıklarının olması, ölçme-değerlendirme açısından yönlendirmesi ve öğrenciyi etkin kılması özelliklerine sahip olmalıdır. Belirtilen özelliklerin yanı sıra müfredatın kurumdan kuruma değişmemesi ve uluslararası öğrencilere Türkçe öğretiminin yurt içinde veya yurt dışında öğretilme durumuna göre şekillenmesi gibi çarpıcı görüşlere de yer verilmiştir. Belirtilen bulguları destekleyen araştırmaların literatürde yer aldığı görülmektedir. Kan, Sülüşoğlu ve Demirel (2013), yabancı dil olarak Türkçe öğretimi programına yönelik okutman görüşlerini değerlendirdikleri araştırmada okutmanların Türk kültürü ve günlük hayatla ilgili sık kullanılan söz varlığının programda yer almasını istedikleri belirlenmiştir. Aynı araştırmada programın 
öğrenci odaklı olması ve dil becerilerine yer vermesi gibi beklentilerin olduğu tespit edilmiştir. İki araştırmanın bulguları birbiriyle örtüşmektedir. Dağdelen (2015), KKTC'deki Doğu Akdeniz Üniversitesi hazırlık okulu yabancı dil olarak Türkçe öğretimi programını öğretmen ve öğrenci görüşlerine göre incelemiştir. Araştırmada müfredat hedeflerinin öğrenci hedeflerini tam olarak karşılamadığı sonucuna ulaşılmıştır. Ayrıca müfredatın Türkçe öğrenen öğrencilerin amaçlarına göre düzenlenmesi gerektiği belirtilmiştir. Er, Biçer ve Bozkırlı (2012) yabancı dil olarak Türkçe öğretimi alanında müfredat hazırlanırken hedef kitlenin yaş, ilgi ve eğitim düzeylerinin dikkate alınmadığını belirtmiştir. Literatürdeki tespitler ile bu araştırmanın bulguları birlikte düşünüldüğünde yabancı dil olarak Türkçe öğretiminde öğrenci ihtiyaçları, yaş ve düzeye göre hazırlanmayan, söz varlığ sıklığı gibi alt boyutları içermeyen bir müfredatın eksik olabileceği sonucu ortaya çıkmaktadır. Bu noktada alana yönelik bazı araştırmacılar tarafından yapılan dil ihtiyaç analizleri ve özel amaçlı program denemeleri dikkate alınmalıdır (Çalışkan \& Çangal, 2013; Koçer, 2013, Şahin, İşcan, Kana \& Koçer, 2013, Temizyürek, Çangal \& Yörüsün, 2015). Ders kitabı yazarları ile literatürde görüşlerine başvurulan öğretmen ve öğrencilerin görüşlerinden hareketle dil ihtiyaç analizlerinin Türkçenin öğretildiği/öğretileceği ülkelerin tamamında yapılması, yine bu ihtiyaçlar dikkate alınarak müfredat ve söz varlığı listeleri hazırlamanın gerekliliği ortaya çıkmaktadır. $\mathrm{Bu}$ gereklilik aynı zamanda bu araştırmada bir (on ikinci yazar) yazarın ifade ettiği "Türkçe öğretiminin yurt içinde veya yurt dişında öğretilme durumuna göre müfredatın şekillenmesi” görüşüyle de uyumludur.

Araştırmanın üçüncü alt bulgusu farklı kurumlara ait müfredatlar olmasıyla ilgilidir. Yazarların yarısı bu durumun öğrenci seviyelerinde kurumlar arası farklılığa neden olduğunu ifade etmiştir. Bu görüşü destekler nitelikte bazı yazarlar ortak müfredat olması gerektiğini savunmuştur. Ayrıca tek merkezden sınav yapılamamasına farklı müfredatların olmasını gerekçe gösteren bir yazarın (birinci yazar) olması da dikkat çekmektedir. Yazarların çoğu farklı müfredatların olmasını sorun olarak değerlendirmektedir. Ünlü'ye (2011) göre yabancı dil olarak Türkçe öğretimi alanında yaşanan önemli sorunlardan biri ortak müfredat olmamasıdır. Kara (2011) ise Türkçeyi yabancılara öğretmeyi amaçlayan kurum/kuruluşların ortak bir müfredat uygulamalarının Türkçe öğretiminin kalitesini arttıracağını, bilimsel çalışmalar ışığında ortak ve evrensel bir müfredatın hazırlanması gerektiğini ifade etmiştir. Literatürdeki bulgular ile bu araştırmada ulaşılan yazar görüşleri, ortak müfredat eksikliğinin çözülmeyi bekleyen kronik bir sorun hâline geldiğini ortaya koymaktadır.

Katılımcıların dinleme becerisi öğretimine ilişkin görüşleri dördüncü alt problemle ilgilidir. En çok dinleme öncesi, sırası ve sonrası gibi stratejilere yer verilmesi gerektiği ifade edilmiştir. Ardından günlük yaşamla ilgili metinlere yer verilmesi, dinlemeyle birlikte izlemenin de olması, metinlerin kaliteli seslendirilmesi, etkinliklerin kısa cevaplı olması ve metinlerin günlük hayata yakın biçimde seslendirilmesi gibi görüşlerin olduğu dikkat çekmektedir. Ayrıca seviyelere göre dinleme metinlerinin kelime sayısının belirlenmesi, metinlerin sık kullanılan kelimeleri içermesi ve dinleme becerisiyle birlikte not alma tekniklerinin öğretilmesi gibi dikkat çekici cevapların olduğu görülmektedir. Literatürde yabancı dil olarak Türkçe öğretiminde dinleme becerisine ilişkin araştırmaların olduğu 
görülmektedir: Tabak ve Göçer (2017), yabancı dil olarak Türkçe öğretiminde kullanılan bazı ders kitaplarındaki A1-C1 düzeyi dinleme etkinliklerini incelemiştir. Araştırmada dinleme etkinliklerinin çoğunun dinleme sonrası etkinliklere yönelik olduğu, dinleme öncesi etkinliklerin ihmal edildiği ve dinleme sırası etkinliklere yeterince yer verilmediği saptanmıştır. $\mathrm{Bu}$ araştırmada ders kitabı yazarlarının dinleme eğitiminde en çok dinleme öncesi, sırası ve sonrası gibi stratejilere yer verilmesi gerektiğini vurgulaması, Tabak ve Göçer'in (2017) araştırmasında tespit edilen eksikliğin hem tekrar ifade edilmesi hem de giderilmesi açısından önemlidir. Memiş (2019) tarafindan dinleme becerisi başarısını artırmak amacıyla yapılan araştırmanın sonucunda sadece işitme duyusuna hitap eden dinleme metinlerinin yerine izleme metinlerinin kullanılmasının öğrencilerin dinlediğini-izlediğini anlama başarısını daha da artırdığı tespit edilmiştir. Ayrıca İşcan'ın (2011) belirttiği "yabancı dil olarak Türkçe öğretiminde nitelikli Türk filmlerinden yararlanılmalı" görüşü izlemenin önemini farklı şekilde ifade etmektedir. Memiş (2019) ile İşcan'ın (2011) tespit ve görüşleri, bu araştırmada yazarların ifade ettiği dinlemenin yanı sıra izlemeye de yer verilmesi tespitiyle paraleldir. Korkmaz (2018), yabanci dil olarak Türkçe öğretimi ders kitaplarındaki dinleme metinlerine yönelik yaptığı araştırmada metinlerdeki kelime sayıları bakımından kitaplar arasında farklılıklar olduğunu saptamıştır. Korkmaz'ın (2018) bulgusu, bu araştırmada ulaşılan seviyelere göre dinleme metinlerinin kelime sayısının belirlenmesi tespitinin gerekli olduğu sonucunu ortaya koymaktadır. Şahbaz ve Çevik (2018), yabancı dil olarak Türkçe öğretiminde not alarak dinleme etkinliğinin yazma becerisine etkisini araştırmıştır. Araştırmada yabancı dil olarak Türkçe öğretiminde A2 ve B1 düzeyinde uygulanan not alarak dinleme etkinliklerinin yazma becerisi üzerinde anlamlı bir etkisinin olduğu belirlenmiştir. Şahbaz ve Çevik'in (2018) ulaştığ sonuç, bu araştırmada beş numaralı yazarın belirttiği dinleme becerisinin yanında not alma tekniklerinin öğretilmesinin elzem olduğu sonucunu aşikâr kılmaktadır. Bunun yanı sıra Koçer (2013), uluslararası öğrencilerin dinlemede aksanları anlamakta sorun yaşadıklarını tespit etmiştir. Koçer'in (2013) bulgusuyla bu araştırmada üç farklı yazarın vurguladığı metinlerin günlük hayata yakın biçimde seslendirilmesi hususu birbiriyle örtüşmektedir.

Ders kitabı yazarlarının konuşma becerisi öğretimine ilişkin görüşleri araştırmanın beşinci alt problemine yönelik cevapları içermektedir. En çok ifade edilen iki görüş konuşma etkinliklerinde yönergelerin olması ve konuşma stratejilerine yer verilmesidir. Ardından karşılıklı konuşma etkinliklerinin göz ardı edilmemesi, konuşma etkinliklerinde grup çalışmalarına yer verilmesi, bütünleşik beceri ile konuşma becerisi etkinlikleri yapılması, günlük hayattan ilgi çekici konuşma konularının seçilmesi, öğretmenin örnek olması ve konuşma etkinliklerinde öğrenci hassasiyetlerine dikkat edilmesi gibi kodların olduğu tespit edilmiştir. Ayrıca öğrenci yanlışlarının uygun bir biçimde düzeltilmesi, konuşma etkinliklerinin dil bilgisi yapılarını tekrar amaçlı içermesi, telaffuz öğretimine ve kültürel etkileşime yer verilmesi gibi dikkat çekici görüşler mevcuttur. Tüm (2020), yabancı öğrencilerin Türkçe konuşma becerileriyle başa çıkma yollarını belirlediği araştırmada Diller İçin Avrupa Ortak Başvuru Metni'nde yer alan bildirişim konularının alt başlıklarının ele alınmasını ve böylece öğrencilerin sadece materyallerde kendilerine sunulan sorulara cevap vermenin yanı sira kendilerini 
ifade etmelerinin sağlanması gerektiğini ifade etmektedir. Tüm'ün (2020) tespitiyle bu araştırmada katılımcıların ifade ettiği "konuşma etkinliklerinde yönergelerin olması" görüşü birbirini desteklemektedir. Çerçi (2018), yabancı dil olarak Türkçe öğretiminde konuşma becerisini ölçme değerlendirmede karşılaşılan sorunları öğretmen görüşlerinden hareketle ortaya koymuştur. Araştırmada, konuşma becerisinin dinleme becerisi ve dil bilgisi konularıyla ilişkisinin göz ardı edildiği saptanmıştır. Çerçi'nin (2018) bulgusuyla katılımcıların ifade ettiği "bütünleşik beceri ile konuşma becerisi etkinlikleri yapılması" ve "konuşma etkinliklerinin dil bilgisi yapılarını tekrar amaçlı içermesi” görüşleri örtüşmektedir. Boylu ve Çangal (2015) ile Şen ve Boylu (2015) yabancı dil olarak Türkçe öğrenen öğrencilerin konuşma kaygılarını ortaya koydukları araştırmalarda sınıf dışında Türkçe pratik yapma imkânı olan öğrencilerin konuşma kaygılarının azaldığını saptamışlardır. Her iki araştırmanın sonuçları, bu araştırma yazarların ifade ettiği "günlük hayattan ilgi çekici konuşma konularının seçilmesi” ve "öğretmenin örnek olması” görüşlerini desteklemektedir. Kurudayığlu ve Sapmaz (2016), yabancı dil olarak Türkçe konuşma öğretiminde öğretmen bilişlerini ortaya koydukları araştırmada konuşma öğretiminin bağımsız değil diğer dil becerileri ile geliştirilmesi gerektiğini belirlemiştir. Kurudayığlu ve Sapmaz'ın (2016) görüşleri, bu araştırmada ulaşılan "bütünleşik beceri ile konuşma becerisi etkinlikleri yapılması" tespitini destekler niteliktedir. Ayrıca Koçer (2013) uluslararası öğrencilerin yaşadığı sorunların başında "sözlü iletişim", "doğru telaffuz" ve "hızlı ifade etme" problemlerinin olduğunu tespit etmiştir. Söz konusu tespit bu araştırmada bir katılımcının belirttiği “telaffuz öğretimi”nin önemini ortaya koymaktadır.

Araştırmanın altıncı alt problemi ders kitabı yazarlarının okuma becerisi öğretimine ilişkin görüşleriyle ilgilidir. Okuma stratejilerine yer verilmesi görüşü en çok ifade edilmiştir. Ardından metinlerin kur seviyelerine ve yaşa uygun olması, öğrencilerin grafik ve tablo okumalarının sağlanması, metinlerin öğrencileri konuşmaya ve yazmaya yönlendirmesi, doğal metinlere yer verilmesi, metinlerin temayla ilgili olması ve seviyelere uygun dil bilgisi yapılarını içermesi gibi görüşler tespit edilmiştir. Alyılmaz ve Şengül (2017), dil öğrenme stratejilerine dayalı etkinliklerin okuma becerilerine yönelik etkisini ortaya koymuştur. Araştırmada stratejilerin öğrencilerin okuma becerisine yönelik başarısını artırdığı ve bilgilerin kalıcılığını sağladığı sonucuna ulaşılmıştır. Bunun yanı sıra Balcı ve Dündar (2017), yabanc1 dil olarak Türkçe öğretiminde okuma stratejileri öğretiminin öğrenci başarısını artırdığ sonucuna ulaşmıştır. Alyılmaz ve Şengül (2017) ile Balcı ve Dündar'ın (2017) tespitleri, yazarların okuma stratejilerine yönelik görüşlerini desteklemektedir. Şimşek (2017), Türkçe okuma metinleri ve okuma kitaplarının yeterliliği ve etkisi ile ilgili uluslararası öğrencilere yönelik yaptığı araştırmada günlük hayatta karşılaşılan ve kullanılan metinlerin daha iyi anlaşıldığı sonucuna ulaşmıştır. Ayrıca öğrencilerin çoğunluğunun ders kitabı dışında okuma kitaplarına ihtiyaç duyması da dikkat çekici bir tespit olarak ortaya konulmuştur. Şimşek'in (2017) tespitleri, bu araştırmada yazarların ifade ettiği doğal metinlere yer verilmesi görüşünü destekler niteliktedir. Maden ve Dincel'in (2017), uluslararası öğrencilerin okuma alışkanlıklarını inceledikleri araştırmada kitap okuma alışkanlığının çoğu öğrencide Türkçe anlama, yazma ve iletişim becerilerini geliştirdiği sonucuna ulaşılmıştır. Bu durum, yazarların belirttiği metinlerin öğrencileri konuşmaya ve 
yazmaya yönlendirmesi görüşüyle paraleldir. Jeon (2017), Güney Kore üniversitelerinde yabancı dil olarak Türkçe öğrenen öğrencilerin okuma becerisinde karşılaştıkları sorunları belirlemiştir. Araştırmada Türkçe okuma derslerinin "okuma öncesi-okuma sıras1-okuma sonrası" sürecine göre uygulanmadığı ve bu durumun öğrencilerin metinle ilgili hiçbir bilgiye ya da ipucuna sahip olmamasına sebep olduğu ortaya çıkmıştır. Ayrıca Türkçe okuma derslerinin, öğrencilerin öğrenme amaçlarını yeterince karşılamadığı ve derslerde kullanılan metinlerin öğrencilerin Türkçe seviyesine uygun bir şekilde seçilmediği tespit edilmiştir. Jeon'un (2017), bulguları, yazarların ifade ettiği okuma stratejilerine yer verilmesi ile metinlerin kur seviyelerine ve yaşa uygun olması görüşlerini haklı çıkarmaktadır.

Araştırmadaki yedinci alt problem yazma becerisi öğretimiyle ilgilidir. Yazma becerisinin diğer becerilerle bütünleşik olması en sık dile getirilen görüştür. $\mathrm{Bu}$ görüşü; yazma etkinliklerinin yönlendirici alt sorular (yönergeler) içermesi, yazma görevleri öncesi örneklerin verilmesi, süreç temelli yazmanın uygulanması, iş birlikli yazma çalışmalarının yapılması, günlük yaşamla ilgili yazma çalışmalarının dikkate alınması, öğretmenin geri bildirim vermesi, yazma etkinliklerinin dil bilgisi yapılarını da içermesi ve yazma öğretiminin akademik yazmaya yönlendirmesi gibi kodlar takip etmiştir. Ayrıca öğrenci yazılarının sınıf ortamında sergilenmesi, yazma becerisi öğretiminin ayrı bir ders olarak yapılması ve yazma etkinliklerinin öğrencilerin Türkçe öğrenme amaçlarına uygun olması gibi dikkat çekici bulgulara ulaşılmıştır. Yaylı ve Yaylı (2018), yabancılara Türkçe öğretimi ders kitaplarındaki yazma etkinliklerini değerlendirmiştir. Araştırmada ders kitaplarında geleneksel olan yaklaşımlarla yazma etkinliklere yer verildiği belirlenmiştir. Ayrıca Öztürk ve Alan (2019), 4+1 planlı yazma ve değerlendirme modelinin Türkçeyi yabancı dil olarak öğrenen öğrencilerin yazma becerilerini geliştirdiğini belirlemiştir. Yaylı ve Yaylı (2018) ile Öztürk ve Alan'ın (2019) tespitleri, bu araştırmada yazarların ifade ettiği süreç temelli yazmanın uygulanması ve iş birlikli yazma çalışmalarının yapılması görüşünü desteklemektedir. Sevim ve Abukan (2020), yazmak için konuş modelinin uluslararası öğrencilerin yazma becerilerine etkisini araştırmıştır. Araştırmada yazma öncesi yapılan konuşma etkinliklerinin Türkçeyi yabancı dil olarak öğrenen öğrencilerin yazma becerilerini olumlu yönde etkilediği sonucuna ulaşılmıştır. Sevim ve Abukan'ın (2020) bulguları, bu araştırmada sıklıkla ifade edilen yazma becerisinin diğer becerilerle bütünleşik olması görüşüyle uyuşmaktadır. Ülper, Çetinkaya ve Bayat'ın (2016) yabancı dil olarak Türkçe öğreten öğretmenlerin taslak metinlere geri bildirim sunma tercihlerini ortaya koydukları araştırmada okutmanların geri bildirim sunmak gerektiğini ifade ettiklerini ve geri bildirimin yazma işlemi biter bitmez yapılmasını belirttiklerini tespit etmiştir. Araştırmacıların tespitleri, ders kitabı yazarlarının ifade ettiği öğretmenin geri bildirim vermesi görüşünü desteklemektedir.

Ders kitabı yazarlarının dil bilgisi öğretimine ilişkin görüşleri araştırmanın sekizinci alt problemine cevap oluşturmaktadır. On yazarın doğrudan dil bilgisi öğretimi yapılması gerektiğini ifade etmesi dikkat çekmektedir. Dil bilgisi öğretiminin metin ve becerilerden bağımsız yapılmaması ile işlevsel dil bilgisi öğretimine yer verilmesi diğer görüşlerdir. Ayrıca bazı yazarlar tarafindan belirtilen öğrencilerin dil bilgisi kurallarını gördüğünde motive olması çarpıcı bir bulgu olarak ifade edilebilir. Göçen (2019), Türkçeyi öğrenen uluslararası öğrencilerin Türkçe dil 
bilgisine ilişkin metaforik algılarını ortaya koyduğu araştırmada öğrenenlerin sıklıkla Türkçe ile kendi dilleri arasında bir benzerlik kurduğunu tespit etmiştir. Bu tespit, yazarların belirttiği öğrencilerin dil bilgisi kurallarını gördüğünde motive olması görüşüyle ilişkilendirilebilir. Söz konusu motivasyonun Türkçe ile kendi dilleri arasında kurulan benzerlik olduğu düşünülebilir. Deniz ve Çekici (2019) ile Benzer'in (2020) işlevsel dil bilgisi ile ilgili yayınları, bu araştırmada bir yazarın vurguladığ1 işlevsel dil bilgisi öğretimine yer verilmesi görüşünü destekler niteliktedir. Aynı zamanda işlevsel dil bilgisi uygulamaları, araştırmanın diğer alt bulgularında ifade edilen öğrenen amacına göre Türkçe öğretiminin yapılmasını kolaylaştırabilir.

Araştırmanın son alt probleminde yazarlar söz varlığı öğretiminin nasıl yapılması gerektiğini belirtmişlerdir. En çok bağlamdan hareketle tahmin etme stratejisinin kullanılması ifade edilmiştir. Daha sonra kur seviyelerine ve temalara göre söz varlığı listelerine yer verilmesi, dil becerilerinin dâhilinde söz varlığı öğretimi yapılması, çeşitli söz varlığı öğretimi stratejilerinin kullanılması, yeni öğrenilen söz varlığından hareketle yazma veya konuşma uygulamalarının yapılması, söz varlığ öğretiminin günlük hayatta sık kullanılan kelimelerden hareketle yapılması, görsellerden destek alınması ve kelime defteri tutturulması yazarların bildirdiği diğer görüşlerdir. Başutku (2018), yabancı dil olarak Türkçe öğretiminde kullanılan ders kitaplarındaki kelime öğretimi stratejilerini tespit etmiştir. Araştırmada en sık kullanılan stratejilerden birinin bağlamdan hareketle kelimenin anlamını tahmin etme olduğu görülmüştür. Bu durum, yazarların ifade ettiği bağlamdan hareketle tahmin etme stratejisinin kullanılması bulgusuyla örtüşmektedir. Aydın (2015), yabancı dil olarak Türkçe öğretiminde kullanılan ders ve okuma kitaplarındaki kelime sıklıklarını tespit ederek seviyelere göre kelime listeleri oluşturmuştur. Aydın'ın (2015) araştırması, ders kitabı yazarlarının ifade ettiği kur seviyelerine ve temalara göre söz varlığı listelerine yer verilmesi görüşüyle paraleldir. Karagöl (2020b), yabancı dil olarak Türkçe öğretiminde kelime defteri tutma stratejisinin söz varlığ1 öğretimine etkisini ortaya koymuştur. Araştırmada kelime defteri tutma stratejisinin söz varlığı dağarcığını geliştirdiği belirlenmiştir. Bu durum, bir yazarın ifade ettiği kelime defteri tutturma görüşü ile örtüşmektedir.

Araştırmanın bulguları ve literatürdeki tespitlerden hareketle -öneri niteliğindeaşağıdaki genel sonuçlara ulaşılmıştır:

1. Yabancı dil olarak Türkçe öğretiminde alandaki akademisyen, öğretmen ve yazarların iş birliğiyle hazırlanan, Türkçe öğreten kurumların resmî olarak dikkate alacağı ortak ve kapsamlı bir müfredata ihtiyaç vardır.

2. İdeal bir yabancı dil olarak Türkçe öğretimi müfredatı öğrencilerin yaş düzeylerini, Türkçe öğrenme amaçlarını ve Türkçenin öğretildiği yeri (yurt içi/yurt dışı) dikkate almalıdır. Ayrıca bu müfredat dil becerilerini geliştirmenin yanı sıra düzeylere göre dil bilgisi yapıları, söz varlığı listeleri ve ölçme değerlendirme yönlendirmelerini içermelidir.

3. Dinleme/izleme becerisi öğretiminde dinleme öncesi, sırası ve sonrası stratejiler göz ardı edilmemelidir. Dinleme/izleme öğretimi günlük yaşamla ilgili metinleri içermelidir. Dinleme/izleme metinlerindeki kelime sayıları kur seviyelerine göre 
belirlenmelidir. Bütünleşik beceri öğretimi ile dinleme/izleme becerisi öğretimi yapılmalidir.

4. Konuşma becerisi öğretiminde etkinlikler alt sorulara sahip olmalıdır. Ayrıca konuşma stratejilerinden yararlanılmalıdır. Bütünleşik beceri öğretimi ile konuşma becerisi öğretimi yapılmalıdır.

5. Okuma becerisi öğretiminde okuma stratejilerine yer verilmelidir. Okuma metinleri kur seviyelerine ve yaşa uygun olmalıdır. Metinler, temayla ilgili olmalıdır ve öğrenilen dil bilgisi yapılarını tekrar amaçlı içermelidir. Bütünleşik beceri öğretimi ile okuma becerisi ögretimi yapılmalıdır.

6. Yazma becerisi öğretimi bütünleşik beceri öğretimi biçiminde yapılmalıdır. Yazma etkinlikleri yönlendirici alt sorular içermelidir. Günlük yaşamla ilgili yazma çalışmalarına yer verilmelidir. Öğretmen, öğrenenlerin yazma ürünlerine geri bildirim vermelidir.

7. Dil bilgisi öğretimi dil becerileri ve metinler dâhilinde doğrudan yapılmalıdır.

8. Söz varlığı öğretiminde çeşitli söz varlığı öğretimi stratejileri kullanılmalıdır. Özellikle bağlamdan hareketle kelimenin anlamını tahmin etme stratejisine yer verilmelidir. Kur seviyelerine ve temalara göre söz varlığı listeleri olmalıdır. Söz varlığı öğretimi dil becerilerinin dâhilinde yapılmalıdır. Yeni öğrenilen söz varlığına öğrenenlerin yazma ve konuşma ürünlerinde yer vermesi sağlanmalıdır.

\section{Çıkar Çatışması ve Etik Bildirimi}

Yazarlar arasında çıkar çatışması bulunmadığını ve tüm araştırmacıların çalışmaya katkı sunduğunu beyan etmiştir. Yazarlar tüm etik kurallara uyduklarını bildirmiştir. Akdeniz Üniversitesi Sosyal ve Beşeri Bilimler Bilimsel Araştırma ve Yayın Etiği Kurulundan 23.12.2020 tarihinde 281 sayılı karar ile araştırmanın etik kurul izni alınmıştır.

\section{Kaynakça}

Alyılmaz, S., \& Şengül, K. (2017). Yabancı dil olarak Türkçe öğretiminde dil öğrenme stratejilerine dayalı etkinliklerin okuma becerilerine yönelik başarıya ve kalıcılığa etkisi. Uluslararası Türkçe Edebiyat Kültür Eğitim Dergisi, 6(1), 361-383.

Aydın, M. (2015). Yabancı dil olarak Türkçe ögretiminde kullanılan ders ve okuma kitaplarındaki kelime sıklığı ve seviyelere göre sözcük hazinesi çalışması [Yüksek lisans tezi]. Gazi Üniversitesi.

Balcı, A., \& Dündar, S. A. (2017). Okuma stratejileri öğretiminin Türkçeyi yabancı dil olarak öğrenen öğrencilerde okuduğunu anlama becerisine etkisi. Ana Dili Eğitimi Dergisi, 5(2), 258-270.

Balcı, M., \& Melanlığlu, D. (2016). Ana dili konuşuru olmayan öğreticilerin görüşlerine göre yabancı dil olarak Türkçe öğretimi. Uluslararası Türkçe Edebiyat Kültür Eğitim Dergisi, 5(2), 986-1004.

Balcı, M., \& Melanlığlu, D. (2020). Türkçenin yabancı dil olarak öğretimi programı üzerine. Kırlkkale Üniversitesi Sosyal Bilimler Dergisi, 10(2), 173-198. 
Başkan, A., \& Ustabulut, M. (2020). Türkçenin yabancı dil olarak öğretiminde anlama becerileri (dinleme ve okuma). RumeliDE Dil ve Edebiyat Araştırmaları Dergisi, 21, 3955 .

Başutku, S. (2018). Türkçenin yabancı dil olarak ögretiminde B1 düzeyinde kelime ögretimi [Yüksek lisans tezi]. Ankara: Başkent Üniversitesi.

Benzer, A. (2020). Yabancı dil olarak Türkçe ögrretiminde işlevsel dil bilgisi. Pegem Akademi.

Boylu, E., \& Çangal, Ö. (2015). Yabancı dil olarak Türkçe öğrenen Bosna Hersekli öğrencilerin konuşma kaygılarının çeşitli değişkenler açısından incelenmesi. Uluslararası Türkçe Edebiyat Kültür Ĕ̈itim (TEKE) Dergisi, 4(1), 349-368.

Çalışkan, N., \& Çangal, Ö. (2013). Yabancılara Türkçe öğretiminde dil ihtiyaç analizi: Bosna Hersek örneği. Abant İzzet Baysal Üniversitesi Eğitim Fakültesi Dergisi, 13(2), 310-334.

Çerçi, A. (2018). Türkçenin yabancı dil olarak öğretiminde konuşma becerisini ölçme değerlendirmede karşılaşılan sorunlar üzerine yabancılara Türkçe öğretenlerin görüşleri. Uludağ Üniversitesi Eğitim Fakültesi Dergisi Yabancı Dil Olarak Türkçenin Öğretimi Özel Saylsı, 3-16.

Dağdelen, D. (2015). Yabancılara Türkçe ögretimi programının öğretmen ve öğrenci görüşlerine göre değerlendirilmesi [Yüksek lisans tezi]. Doğu Akdeniz Üniversitesi.

Demirel, Ö. (1989). Yabancı dil öğretmenlerinin yeterlikleri. Hacettepe Üniversitesi Eğitim Fakültesi Dergisi, 4, 5-26.

Deniz, K., \& Çekici, Y. E. (2019). Yabancı dil olarak Türkçe öğretimi açısından toplu taşıma araçlarında dil işlevleri. International Journal of Languages Education, 7(4), 24-36.

Derman, S. (2010). Yabancı uyruklu öğrencilerin Türkiye Türkçesi öğreniminde karşılaştıkları sorunlar. Selçuk Üniversitesi İlahiyat Fakültesi Dergisi, 29, 227-247.

Elemen, B. (2018). Türkçeyi ikinci dil olarak öğrenen yabancı uyruklu ögrrencilerin lisans düzeyinde kullandıkları dinleme stratejileri [Yüksek lisans tezi]. Çanakkale Onsekiz Mart Üniversitesi.

Er, O., Biçer, N., \& Bozkırlı, K. Ç. (2012). Yabancılara Türkçe öğretiminde karşılaşılan sorunların ilgili alan yazını ışı̆̆ında değerlendirilmesi. Uluslararası Türkçe Edebiyat Kültür Eğitim Dergisi, 1(2), 51-69.

Fişekçioğlu, A. (2020). Yabancı dil olarak Türkçe öğretimine giriş açıklamalı ana kavramlar el kitabl. Nobel Yayıncilık.

Göçen, G. (2019). Türkçeyi yabancı dil olarak öğrenenlerin “Türkçenin dil bilgisi”ne yönelik metaforik algisı. Başkent University Journal of Education, 6(1), 28-45.

Göçer, A. (2009). Türkiye'de Türkçeyi yabancı dil olarak öğrenen lise öğrencilerinin hedef dile karşı tutumlarının bazı değişkenler açısından incelenmesi. Turkish Studies, 4(8), 1298-1313.

Güler, E. B. (2012). Yabancılara Türkçe öğretiminde "öğretmen” unsuru. The Journal of Academic Social Science Studies, 5(2), 129-134.

İşcan, A. (2011). Yabancı dil olarak Türkçe öğretiminde filmlerin yeri ve önemi. Turkish Studies, 6(3), 939-948. 
Jeon, K. (2017). Güney Kore üniversitelerinde yabancl dil olarak Türkçe öğrenen ögrencilerin okuma becerisinde karşılaştıkları sorunlar [Yüksek lisans tezi]. Hacettepe Üniversitesi.

Kan, M. O., Sülüşoğlu, B., \& Demirel, Ö. (2013). Yabancı dil olarak Türkçe öğretimi programı ile ilgili okutman ve öğrenci görüşlerinin değerlendirilmesi. Mustafa Kemal Üniversitesi Sosyal Bilimler Enstitüsü Dergisi, 10(24), 29-42.

Kara, M. (2011). Avrupa dilleri öğretimi ortak çerçeve metni doğrultusunda Türkçe öğrenen yabanc1lara A1-A2 seviyesinde Türkçe öğretim programı örneği. Zeitschrift für die Welt der Türken, 3(3), 157-195.

Karababa, Z. C. (2009). Yabancı dil olarak Türkçenin öğretimi ve karşılaşılan sorunlar. Ankara Üniversitesi Eğitim Bilimleri Fakültesi Dergisi, 42(2), 265-277.

Karababa, Z. C. (2010). Türkçenin Yabancı dil olarak öğretimi ve bu alan için öğretmen yetiştirmenin önemi ve gereği. İ. H. Altınok \& Y. Yeniçerioğlu (Ed.), T.C. MEB Ögrretmen Yetiştirme Genel Müdürlüğ̈̈ Yabancl Dil Olarak Türkçe Öğretimi ve Öğretmenliği Çalıştayı Kitabı. (ss. 26-30).

Karagöl, E. (2020a). Yenilenmiş Bloom taksonomisine göre güncel Türkçe öğretim programlar1. Journal of Language Education and Research, 6(1), 56-71.

Karagöl, E. (2020b). The effects of vocabulary notebook strategy on the teaching of vocabulary in teaching Turkish as a foreign language. International Journal of Eurasian Education and Culture, 5(9), 745-778.

Kaya, M., \& Kardaş, M. (2020). Yabancı dil olarak Türkçe öğretim programı üzerine inceleme. Kuram ve Uygulamada Sosyal Bilimler Dergisi, 4(1), 1-20.

Koçer, Ö. (2013). Program geliştirmenin ilk basamağı: yabancı dil olarak Türkçe öğretiminde ihtiyaç ve durum analizi. Eğitim ve Bilim, 38(169), 159-174.

Korkmaz, C. B. (2018). Yabancl dil olarak Türkçenin öğretiminde kullanılan dinleme metinlerinin incelenmesi ve değerlendirilmesi [Doktora tezi]. Ankara, Gazi Üniversitesi.

Kurt, B. (2020). Yabancı dil olarak Türkçe öğretimi sertifika programına ilişkin kursiyer görüşlerinin karşılaştırmalı bir analizi. Akdeniz Üniversitesi Eğitim Fakültesi Dergisi, $3(1), 73-90$.

Kurt, B., Direkci, B., \& Caner, M. (2018). Yabancı dil olarak Türkçe öğretimine ilişkin İngilizce öğretmeni adaylarının görüşleri. Turkish Studies, 13(27), 1017-1037.

Kurudayığlu, M., \& Sapmaz, S. (2016). Yabancı dil olarak Türkçe konuşma öğretimine dair öğretmen bilişleri. Zeitschrift Für Die Welt Der Türken, 8(3), 85-102.

Maden, S., \& Dincel, Ö. (2017). Yabancı uyruklu öğrencilerin Türkçe okuma alışkanlıkları. Uluslararası Türk Eğitim Bilimleri Dergisi, 2017(9), 125-140.

Memiş, M. R. (2019). Türkçe öğrenenlerin dinleme başarısını artırmak için kullanılabilecek iki farklı uygulama. Ondokuz Mayıs Üniversitesi Eğitim Fakültesi Dergisi, 38(2), 107120.

Mete, F. (2012a). Türkçeyi yabancı dil olarak öğreten ögretmenlerin özel alan yeterlikleri üzerine bir araştırma [Yayımlanmamış doktora tezi]. Ankara, Gazi Üniversitesi.

Mete, F. (2012b). Yabanc1 dil olarak Türkçe öğretimine ilişkin öğretmen görüşlerinin değerlendirilmesi. Dede Korkut Türk Dili ve Edebiyatları Araştırmaları Dergisi, 1(1), 102-125. 
Mete, F., \& Gürsoy, Ü. (2013). Yabancı dil olarak Türkçe öğretiminde öğretmen yeterliklerine ilişkin görüssler. Hacettepe Üniversitesi Eğitim Fakültesi Dergisi, 28(3), 343-356.

Öztürk, J., \& Alan, Y. (2019). 4+1 Planlı yazma ve değerlendirme modelinin Türkçeyi yabancı dil olarak öğrenen öğrencilerin yazma becerilerine etkisi. Mustafa Kemal Üniversitesi Sosyal Bilimler Enstitüsü Dergisi, 16(44), 221-250.

Saban, A., \& Ersoy, A. (2019). Eğitimde nitel araştırma desenleri. Anı Yayıncılık.

Sallabaş, M. E. (2012). Türkçeyi Yabancı dil olarak öğrenenlerin konuşma kaygılarının değerlendirilmesi. Turkish Studies, 7(3), 2199-2218.

Seggie, N. F., \& Bayyurt, Y. (2015). Nitel araştırma yöntemi. F. N. Seggie \& Y. Bayyurt (Ed.), Nitel araştırma yöntem, teknik, analiz ve yaklaşımları (ss. 11-22). Anı Yayıncılık.

Sevim, O., \& Abukan, M. (2020). Yazmak için konuş modelinin Türkçeyi yabancı dil olarak öğrenen öğrencilerin yazma becerilerine etkisi. Munzur Üniversitesi Sosyal Bilimler Dergisi (MÜSBID), 9(1), 79-104.

Şahbaz, N., \& Çevik, B. (2018). Yabancı dil olarak Türkçenin öğretiminde not alarak dinleme etkinliğinin yazma becerisine etkisi. Mehmet Akif Ersoy Üniversitesi Eğitim Fakültesi Dergisi, 48, 201-218.

Şahin, E., İşcan, A., Kana, F., \& Koçer, Ö. (2013). Yabancı dil olarak Türkçe öğrenen öğrencilerin ihtiyaç algıları: Betimsel bir durum çalışması. The Journal of Academic Social Science Studies, 6(4), 1185-1198.

Şen, Ü., \& Boylu, E. (2015). Türkçeyi yabancı dil olarak öğrenen İranlı öğrencilerin konuşma kaygılarının değerlendirilmesi. Mustafa Kemal Üniversitesi Sosyal Bilimler Enstitüsü Dergisi, 12(30), 13-25.

Şimşek, P. (2017). Yabancı dil olarak Türkçenin öğretiminde temel materyaller: okuma metinleri ve okuma kitapları. Uluslararası Türk Eğitim Bilimleri Dergisi, 2017(8), 211225.

Tabak, G., \& Göçer, A. (2017). Türkçenin yabancı dil olarak öğretiminde A1-C1 düzey dinleme etkinliklerinin incelenmesi. Cumhuriyet Uluslararası Eğitim Dergisi, 6(3), 400411.

Tavşancıl, E., \& Aslan, A. E. (2001). Sözel, yazılı ve diğer materyaller için içerik analizi ve uygulama örnekleri. Epsilon Yayınevi.

Temizyürek, F, Çangal, Ö., \& Yörüsün, S. (2015). Yabancılara Türkçe öğretiminde iş Türkçesi öğretim programı, ders kitabı ve terimler sözlüğü denemesi: bankacıllk örneği. Zeitschrift für die Welt der Türken, 7(2), 87-111.

Tüm, G. (2020). Yabancı öğrencilerin Türkçe konuşma becerileriyle başa çıkma yolları üzerine bir çalışma. T. Balc1, A. O. Öztürk \& M. Aksöz (Ed.), Schriften zur Sprache und Literatur IV (1. Bask1, ss. 387-398). IJOPEC Publication Limited.

Türkiye Maarif Vakfi. (2019). Yabancl dil olarak Türkçe öğretimi programı. https://www.turkiyemaarif.org/uploads/yabancidilolarakturkceogretimi.pdf

Ustabulut, M., \& Kara, M. (2019). Yansıtıcı düşünme becerileri eğitiminin yabancı dil olarak Türkçe öğreten öğretmenlerin ölçme ve değerlendirme sürecinin gelişimine etkisi. Bayburt Eğitim Fakültesi Dergisi, 14(27), 122-146. 
Ustabulut, M., \& Keskin, S. (2020). Yabancı dil olarak Türkçe eğitimi alan uluslararası öğrencilerin öğrenme etkinliğini geliştirme amaçlı sosyal medya kullanım-doyum motivasyonları. Ondokuz Mayıs Üniversitesi Eğitim Fakültesi Dergisi, 39(1), 155-173.

Ülper, H., Çetinkaya, G., \& Bayat, N. (2016). Yabancı dil olarak Türkçe öğreten öğretmenlerin taslak metinlere yönelik geribildirim sunma tercihleri. Istanbul Aydın Üniversitesi TÖMER Dil Dergisi, 1(1), 31-46.

Ünlü, H. (2011). Türkiye'de ve dünyada Türkçenin yabancılara öğretiminde karşılaşılan sorunlar ve çözüm önerileri. Gazi Üniversitesi Türkçe Araştırmaları Akademik Öğrenci Dergisi, l(1), 108-116.

Yaylı, D., \& Yaylı, D. (2018). Yabancılara Türkçe öğretimi ders kitaplarında yazma etkinliklerinin değerlendirilmesi (Yedi İklim Türkçe örneği). Pamukkale Üniversitesi Eğitim Fakültesi Dergisi, 44, 132-145.

Yıldırım, A., \& Şimşek, H. (2008). Sosyal bilimlerde nitel araştırma yöntemleri. Seçkin Yayıncilik.

\section{Extended Abstract}

In teaching Turkish as a foreign language, the views of teachers and students generally gain intense. It is seen that the authors of the textbooks, who have an important place in the functioning of the field, are neglected in scientific research. However, textbook authors are an important stakeholder who not only produce works but also provide the connections of the field of teaching Turkish as a foreign language. The aim of this research is to reveal the opinions of the textbook authors on teaching Turkish as a foreign language. In order to carry out detailed investigations for this purpose, the following sub-problems have been identified:

1. What curriculum did the authors use when creating the textbook?

2. According to the authors, how should the curriculum be for teaching Turkish as an ideal foreign language?

3. How do the authors evaluate the different curricula of various institutions?

4. According to the authors, what should / should be an ideal listening / watching skills teaching?

5. According to the authors, what should / should be an ideal speaking skill instruction?

6. According to the authors, what should / should be an ideal teaching of reading skills?

7. According to the authors, what should / should be an ideal writing skill teaching?

8. What are the authors' opinions about grammar teaching?

9. How should vocabulary teaching be done according to the authors? Which strategies should be used in vocabulary teaching?

This research, which was conducted to examine the views of the coursebook authors on teaching Turkish as a foreign language, was designed in a qualitative design. Thirteen authors were interviewed within the scope of the research. The years of seniority of the participants vary between 5-22 years. 8 participants are graduate graduates, 4 participants are doctorate and 1 participant is undergraduate. 
In addition, the authors of the study group have the experience of actively lecturing at TÖMER. The research data were collected with a semi-structured interview form. Questions were created in line with the themes of "program", "skills", "grammar" and "vocabulary" by scanning the literature. Based on these questions, the form titled "Teaching Turkish as a Foreign Language According to the Opinions of Textbook Authors" was sent to 3 field experts.

The interview with the authors was written in Microsoft Office Word program with Times New Roman font, 12 font size, $2.5 \mathrm{~cm}$ page margins and 1.5 line spacing. 44194 words of data, consisting of 117 pages, were obtained.

Content analysis technique was used for the analysis of the data in this study. The sub problem sentences of the study guided the collection of data. For this reason, deductive content analysis was used in the study. The themes in the research were determined at the beginning of the research process. The categories and codes of the research were reached during the analysis process.

The following general conclusions were reached in the study:

1. In teaching Turkish as a foreign language, there is a need for a common and comprehensive curriculum prepared in cooperation with academicians, teachers and authors in the field and which will be officially taken into account by Turkish teaching institutions.

2. The curriculum for teaching Turkish as an ideal foreign language should take into account the age levels of the students, the purpose of learning Turkish and the place where Turkish is taught (in the country / abroad). In addition, this curriculum should include grammar structures, vocabulary lists, and assessment and evaluation guidelines by level, as well as improving language skills.

3. In teaching listening / watching skills, strategies before, during and after listening should not be overlooked. Listening / watching instruction should include texts about daily life. The number of words in the listening / watching texts should be determined according to the level of the exchange rate. Teaching listening / watching skills should be done with integrated skill teaching.

4. Activities in teaching speaking skills should have sub-questions. In addition, speaking strategies should be used. Speaking skills should be taught with integrated skill teaching.

5. Reading strategies should be included in teaching reading skills. Reading texts should be appropriate for exchange level and age. Texts should be theme-related and reproduce the grammatical structures learned. Teaching reading skills should be done with integrated skill teaching.

6. Teaching writing skills should be done in the form of integrated skills teaching. Writing activities should include guiding sub-questions. Writing studies related to daily life should be included. The tutorial should give feedback on the learners' writing products.

7. Grammar teaching should be done directly within language skills and texts. 
8. Various vocabulary teaching strategies should be used in vocabulary teaching. The strategy of guessing the meaning of the word, especially from the context, should be included. There should be vocabulary lists according to currency levels and themes. Vocabulary teaching should be done within language skills. It should be ensured that learners include the newly learned vocabulary in their writing or speaking products. 